\title{
The afterlives of Galway jail, 'difficult' heritage, and the Maamtrasna Murders: representations of an Irish urban space, 1882-2018
}

\author{
Richard J. Butler
}

3 May 2019

\begin{abstract}
This article explores the spatial history and 'afterlives' of Galway jail, where an innocent man, Myles Joyce, was executed in 1882 following his conviction for the Maamtrasna Murders; in 2018 he was formally pardoned by President Michael D. Higgins. The article traces how the political and cultural meanings of this incident were instrumentalised in the building of Ireland's last Catholic cathedral on the site of the former Galway jail. It analyses how the site was depicted in different ways and at different moments - as one of justice, of injustice, of triumph, and of redemption. It investigates how these different legacies were instrumentalised - or at times ignored - by Irish nationalists and later by the Catholic bishop of Galway, Bishop Michael Browne. It uses Joyce's execution to explore the site's legacy, an incident that at times dominated its representations but at other moments faded from prominence. The article situates the former jail site within theoretical writings on memorialisation, 'difficult' heritage, and studies of architectural demolition, while also commenting on mid-twentieth-century Irish Catholic politics and culture.
\end{abstract}

\section{Keywords}

Urban history; heritage; memory; Roman Catholic church; Galway 


\section{Article}

President Michael D. Higgins, standing in the carpark adjoining Galway cathedral, on 18 August 2018, watched as a wreath was laid at the grave of Myles Joyce (Maolra Seoighe), a man hanged in the execution yard of the former Galway jail following his conviction for the infamous 'Maamtrasna murders' of 1882 (Fig. 1 [landscape]). ${ }^{1}$ Some months earlier, following an expert report by Niamh Howlin on the shortcomings of his trial, Higgins issued a formal pardon (maithiúnas) noting that Joyce's conviction for murder was 'unsafe according to the standards of the time'. ${ }^{2}$ The development marked a major milestone in a long-running campaign to clear his name, and it also was the first time that a pardon had been issued for events predating the foundation of the state. ${ }^{3}$ At the same time Margaret Kelleher published a new and definitive history of the incident, which delves in unprecedented detail into the issues of language at the centre of the miscarriage of justice. Her work follows a widely acclaimed study from the early 1990s by a local parish priest, Fr. Jarlath Waldron, that helped raise awareness of the case. ${ }^{4}$ Both Kelleher and Waldron highlight the gruesome and macabre scene of Joyce's execution (along with the two other men convicted of the murders): his emotional protests of innocence in the

\footnotetext{
${ }^{1}$ RTÉ Six One news (TV), 18 Aug. 2018; Connacht Tribune, 18 Aug. 2018; Margaret Kelleher, The Maamtrasna murders: language, life and death in nineteenth-century Ireland (Dublin, 2018), p. 193.
}

${ }^{2}$ Niamh Howlin, Report on the trial of Myles Joyce, November 1882 (July 2017, available online); Irish Times, 4, 7 Apr. 2018; Kelleher, Maamtrasna, pp. 215-16, 227-8.

${ }^{3}$ Kelleher, Maamtrasna, p. xxi; Seán Ó Cuirreáin, Éagóir: Maolra Seoighe agus dúnmbaruithe Mhám Trasna (Baile Átha Cliath, 2016), pp. 276-82.

${ }^{4}$ Jarlath Waldron, Maamtrasna: the murders and the mystery (Dublin, 1992). See also James H. Murphy, Ireland's czar: Gladstonian government and the Lord Lieutenancies of the Red Earl Spencer, 1868-86 (Dublin, 2014), pp. 230-7; Patrick Joyce, The state of freedom: a history of the British state since 1800 (Cambridge, 2013), pp. 303-7; Ó Cuirreáin, Éagóir, Kelleher, Maamtrasna, p. 217. 
Irish language, the botched hanging, his long and agonising death, and most of all the rapid mobilisation of the case by Irish nationalists such as the M.P. Tim Harrington. ${ }^{5}$ Following Deborah Cherry, this article explores the spatial history and 'afterlives' of the jail where Joyce was executed. ${ }^{6}$ It explores how the political and cultural meanings and memories of the event were instrumentalised in the building of Ireland's last Catholic cathedral. It focuses on memorial dynamics and on the subjectivities of the site itself, which rarely if ever offered a simple or straightforward narrative. More broadly, the article explores four key themes: first, how issues of memory and legacy affected an Irish urban space as it was transformed from jail to cathedral in the mid-twentieth century. Second, how the site was depicted - in different ways and at different moments - as one of justice, of injustice, of triumph, and of redemption. Third, the article explores how these different legacies were instrumentalised - or at times ignored - by Irish nationalists and later by a Catholic bishop, and how they interacted with the physicality and spatiality of such a large urban space. Fourth, it uses the case-study of Joyce and the Maamtrasna murders to explore the site's legacy, an incident that at times dominated its representations but at other moments faded from prominence. The analysis situates the former jail site within theoretical writings on memorialisation, 'difficult' heritage, and studies of architectural demolition. It also comments more broadly on mid-century Irish Catholic politics and culture, making extensive use of the private papers of Michael Browne (1895-1980), bishop of Galway, Kilmacduagh, and Kilfenora from 1937 to $^{1976 .}{ }^{7}$

\footnotetext{
5 Waldron, Maamtrasna, pp. 133-54, 193-213; Kelleher, Maamtrasna, pp. 134-74.

${ }^{6}$ Deborah Cherry, 'The afterlives of monuments’, South Asian Studies, xxix, no. 1 (Mar. 2013), pp. 1-14.

${ }^{7}$ In recent years scholars have begun to use the Browne papers - see for example James S. Donnelly, Jr., 'Bishop Michael Browne of Galway (1937-76) and the regulation of public morality', New Hibernia Review, xvii, no. 1 (2013), pp. 16-39; Gerard Madden, 'Bishop Michael Browne of Galway and anti-Communism’,
} 


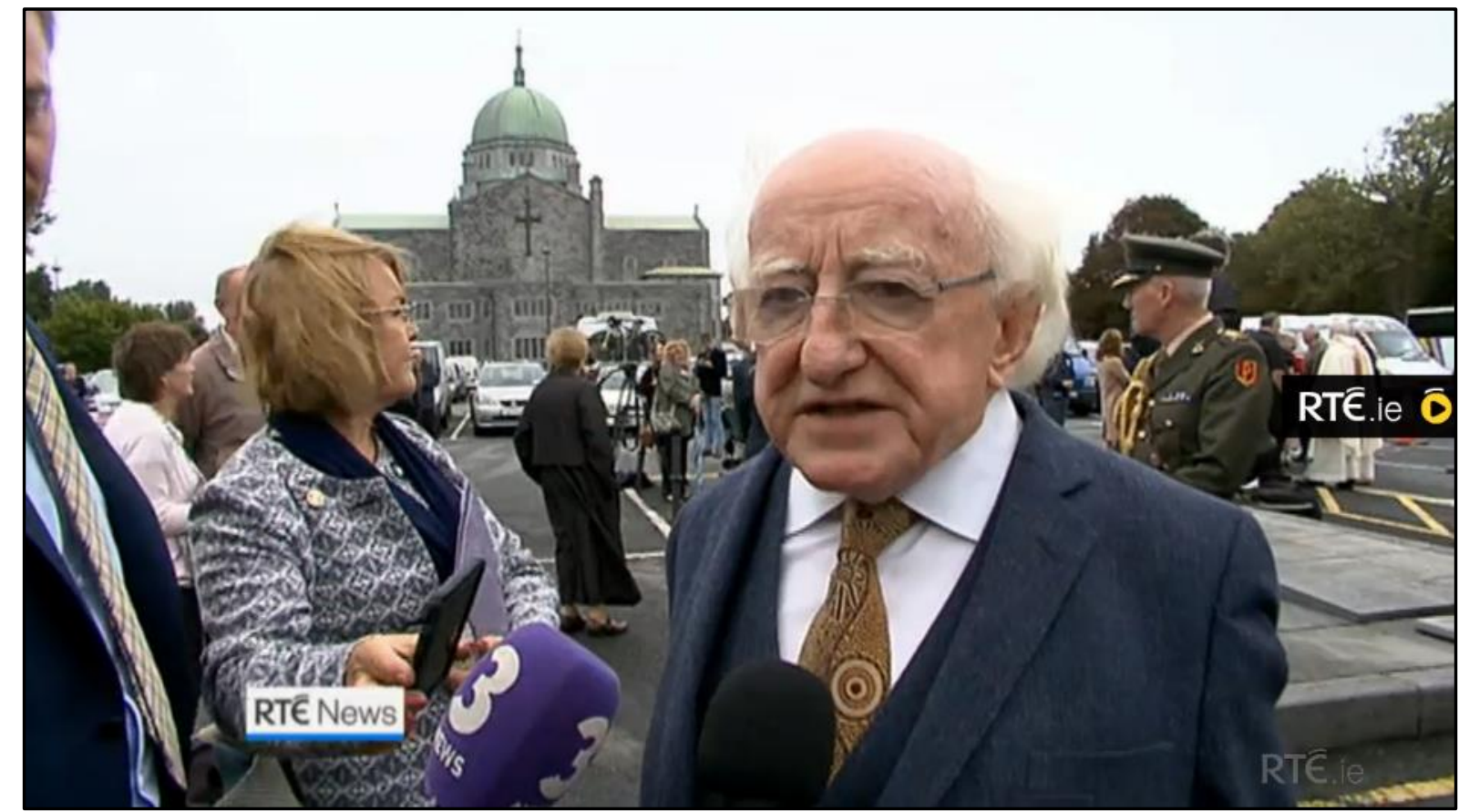

Fig. 1. President Michael D. Higgins in Galway. RTÉ Six One news (TV), 18 Aug. 2018.

The building of Galway jail had passed out of living memory by the time news broke of the shocking details of the Maamtrasna murders. The jail, the work of the architects Thomas Hardwick and Richard Morrison, had been built between 1804 and 1810 during a wave of prison reconstruction that swept the British Isles. ${ }^{8}$ Its cell blocks were arranged in a polygonal fashion

Saothar, no. 39 (2014), pp. 21-31; Richard J. Butler, 'Catholic power and the Irish city: modernity, religion, and planning in Galway, 1944-49', forthcoming.

${ }^{8}$ Galway county gaol act, 1802 (42 Geo. III, c. xviii); James Hardiman, The history of the town and county of the town of Galway (Dublin, 1820), pp. 300-5; James Mitchell, 'The prisons of Galway: background to the inspector general's reports, 1796-1818', Journal of the Galway Archaeological and Historical Society, xlix (1997), pp. 1-21, Richard J. Butler, Building the Irish courthouse and prison: a political history, 1750-1850, forthcoming. The site comprised two jails - a county jail built between 1804 and 1810 and a smaller adjacent town gaol built between 1807 and 1810. The jails were merged in c. 1866 - see Samuel Ussher Roberts, 
around a central governor's residence, similar to the jails built around the same time in Sligo, Roscommon, and elsewhere. Facing the River Corrib and a new bridge that linked the jail with a new courthouse was an austere gatehouse, and surrounding it the bleak spectacle of 500 metres of a high boundary wall. ${ }^{9}$ Inside there was a hospital, a chapel, a tread-mill, and - once public executions were outlawed in Britain and Ireland in 1868 - a yard used for executions. ${ }^{10}$ At almost four acres, the jail site dominated the western half of the town.

The jail took on a special significance following the brutal murder of five members of the Joyce family in west Connemara in the townland of Mám Trasna on 17 August 1882. There was early speculation - later downplayed - that the incident was linked to the Land War and the murders of bailiffs, agents, and landlords in the region. Seven men broke into the Joyce family home, killing (or grievously injuring) John, his wife Bridget, his stepson Michael, his mother Margaret, his daughter also Margaret, and his son Patsy. The ferocity of the incident shocked even the news reporters of the time, conditioned as they were to rural violence, and especially the barbarous violence directed at the women. ${ }^{11}$ Ten men - among them Caseys and Joyces from the interwoven families of the area - were quickly arrested and sent forward for trial at Dublin's Green Street courthouse in November 1882. Two gave evidence against the others and escaped jail, five were given life imprisonment, and three - Patrick Joyce, Patrick Casey, and Myles Joyce - were sentenced to be hanged. Prior to their execution, two of the three admitted their

correspondence and drawings relating to work at Galway county gaol, 1858-66 (Galway County Archives (G.C.A.), GS-11-02).

${ }^{9}$ Hardiman, History, p. 301.

${ }^{10}$ Kelleher, Maamtrasna, pp. 137-9; W. E. Vaughan, Murder trials in Ireland, 1836-1914 (Dublin, 2009), p. 328.

${ }^{11}$ Galway Express, 19 Aug. 1882; Freeman's Journal, 21 Aug. 1882. 
involvement but claimed that Myles Joyce was entirely innocent. Joyce's brief trial had been marred by what Howlin describes as 'witness evidence ... of doubtful reliability' and 'procedural irregularities, in particular in relation to language and translation' between English and Irish. ${ }^{12}$ John Spencer, the viceroy, declined at the last moment to commute Joyce's sentence, and all three men were hanged by William Marwood inside Galway jail on 15 December $1882 .{ }^{13}$ Two of the other men died in prison and the remaining three were released in October $1902 .{ }^{14}$ The case - and Joyce's hanging in particular - quickly became, as Kelleher comments, 'a cause célèbre for Irish nationalists and a recurring subject for parliamentary comment in the later $1880 \mathrm{~s}^{\prime} .{ }^{15}$

Ireland's long nineteenth century provides no shortage of politically charged - and often 'difficult' - sites of memory, including many former prisons. Dublin's Kilmainham jail housed generations of political prisoners, was the site of the execution of the Easter Rising leaders, and more problematically - where Free States forces executed four anti-treaty rebels in 1922. The transformation from British prison to de-facto national museum was a slow and contentious one, sullied by this Civil War legacy and later the Northern Irish conflict, in which forgetting certain aspects of the jail's dark history was as important as remembering others. Here there are many parallels with Galway jail: the variety of suggested future uses after closure, the prospect of complete demolition, and the (re)construction of the site in the mid-1960s. ${ }^{16}$ Recent scholarship

\footnotetext{
${ }^{12}$ Howlin, Report on the trial of Myles Joyce, pp. 31-2. Similar conclusions are reached in Noel McAree, Murderous justice: a study in depth of the infamous Connemara murders (Limerick, 1990), pp. 91-117.

${ }^{13}$ For the inquest held in the jail soon afterwards, see National Archives of Ireland (N.A.I.), CSORP 1883/189, and Kelleher, Maamtrasna, pp. 142-47. I am grateful to Margaret Kelleher for this reference. ${ }^{14}$ Murphy, Ireland's czar, pp. 230-7; Kelleher, Maamtrasna, pp. xv-xvii, 134-48.

${ }^{15}$ Kelleher, Maamtrasna, pp. xviii, xxi; Vaughan, Murder trials in Ireland, pp. 143, 289-90, 294, 353.

${ }^{16}$ Freida Kelly, $A$ bistory of Kilmainham gaol: the dismal house of little ease (Cork, 1988); Pat Cooke, $A$ bistory of Kilmainham gaol, 1796-1924 (Dublin, 1995); Pat Cooke, 'Kilmainham gaol: confronting change', Irish Arts
} 
highlights the difficult heritage of other Irish prison sites - Spike Island, Sligo gaol, Wicklow gaol, Cork gaol - as well as their ongoing commodification as sites of 'dark tourism'. ${ }^{17}$ Beyond penal institutions, public monuments in Irish cities (such as Nelson's Column in Dublin) and the 'big houses' of the Anglo-Irish ascendancy also represent sites of competing heritage and memory, and both were subject to purposeful attack and demolition in the first few decades of the Free State. ${ }^{18}$ Furthermore, the conflict in Northern Ireland has initiated new debates about

Review, xxiii (2002), pp. 42-5; Eric Zuelow, 'Enshrining Ireland's nationalist history inside prison walls: the restoration of Kilmainham jail', Éire-Ireland, xxxix, nos. 3-4 (2004), pp. 180-201; Mark McCarthy, Ireland's 1916 Rising: Explorations of history-making, commemoration \& heritage in modern times (Ashgate, 2012), pp. 21839, 305-28; Niamh O'Sullivan, Every dark hour: a history of Kilmainham jail (Dublin, 2007); Rory O’Dwyer, The Bastille of Ireland: Kilmainham gaol, from ruin to restoration (Dublin, 2010).

${ }^{17}$ Siobhán Ryan, 'Sligo gaol', National Inventory of Architectural Heritage (NIAH) 'Building of the month', Oct. 2018 (available at: http://www.buildingsofireland.ie/Surveys/Buildings/BuildingoftheMonth/Archive/Name,3439,en.html ); Gillian O’Brien, 'Doing time: dark tourism in Ireland', RTÉ Brainstorm, 25 July 2018 (available at: https://www.rte.ie/eile/brainstorm/2017/1031/916396-doing-time-dark-tourism-in-ireland); Philip R. Stone, 'A dark tourism spectrum: towards a typology of death and macabre related tourist sites, attractions and exhibitions', Tourism: An Interdisciplinary International Journal, liv, no. 2 (2006), pp. 145-60. ${ }^{18}$ Yvonne Whelan, 'The construction and destruction of a colonial landscape: monuments to British monarchs in Dublin before and after independence', Journal of Historical Geography, xxviii, no. 4 (Oct. 2002), pp. 508-33; Yvonne Whelan, Reinventing modern Dublin: streetscape, iconography and the politics of identity (Dublin, 2003); Robert Bevan, The destruction of memory (London, 2006), p. 70; Terence Dooley, The decline of the Big House in Ireland (Dublin, 2001); Terence Dooley, 'The fate of country houses in the nineteenth and twentieth centuries', in Andrew Carpenter, Rolf Loeber, Hugh Campbell, Livia Hurley, and Ellen Rowley (eds), Art and arcbitecture of Ireland: volume IV: architecture 1600-2000 (Dublin, New Haven and London, 2014), pp. 384-7. 
the future of 'difficult' heritage sites there, such as the former Maze prison. ${ }^{19}$ This article is the first attempt to situate Galway jail within this broader historiography.

This study is influenced by Guy Beiner's work on Irish memory. ${ }^{20}$ Beiner notes the deep cultural memories associated with Irish nationalist 'martyrs' from the mid-nineteenth century onwards. ${ }^{21}$ As Kelleher shows, Joyce quickly became a kind of political martyr, taking his place alongside the Fenian 'Manchester martyrs' and - in later years - the Easter Rising leaders. ${ }^{22}$ In his study of the memories of the 1798 rebellion, Beiner focuses on the legacy - the memorialisation and (in some cases) the disremembering - of military battles in particular lieux de

${ }^{19}$ Sara McDowell, Negotiating places of pain in post-conflict Northern Ireland: debating the future of the Maze/Long Kesh', in William Logan and Keir Reeves (eds), Places of pain and shame: dealing with 'difficult heritage' (Abingdon, 2009), pp. 215-30. For 'difficult' heritage in Belfast, see Peter Shirlow, 'Belfast: the “post-conflict” city', Space and Polity, x, no. 2 (2006), pp. 99-107; Johnny Byrne and Cathy GormleyHeenan, 'Beyond the walls: dismantling Belfast's conflict architecture', City, xviii, no. 4 (2014), pp. 44754. The site of Bloody Sunday in the Bogside in Derry is yet one more example.

${ }^{20}$ Guy Beiner, Remembering the year of the French: Irish folk history and social memory (Madison, WI., 2006); Guy Beiner, 'Between trauma and triumphalism: the Easter Rising, the Somme, and the crux of deep memory in modern Ireland', Journal of British Studies, xlvi, no. 2 (Apr. 2007), pp. 366-89; Guy Beiner, Forgetful remembrance: social forgetting and vernacular historiography of a rebellion in Ulster (Oxford, 2018); Guy Beiner, 'A short history of Irish memory in the long twentieth century', in Thomas Bartlett (ed.), The Cambridge history of Ireland: volume IV: 1880 to the present (Cambridge, 2018), pp. 708-25.

${ }^{21}$ Guy Beiner, 'Between trauma and triumphalism', pp. 375-9.

${ }^{22}$ Kelleher, Maamtrasna, pp. 151-74. 
mémoire (sites of memory) such as Antrim town, Ballynahinch, Castlebar, and Ballinamuck. ${ }^{23}$ In this article the legacy and memory of the former Galway jail site and its transformation into a Catholic cathedral is considered as a biography of an urban space, with attention focused on the visual, spatial, and tangible aspects of the site's history - from the immovable physicality of the jail's burial plot to the photographic records of the jail walls being demolished and how the site appeared from different vantage points in the city. It takes the former jail site as a lieu de mémoire in its own right, tracing how it acquired such a rich 'sedimentation' of meanings through its long history and how these were later 'reread, reanalysed, and reworked'. ${ }^{24}$ Following Carsten Paluden-Müller, this study argues that different memories can be attached to the same site at different moments and by different actors, and also that these memories can be reinvigorated as easily as they can be forgotten. ${ }^{25}$ The jail site was not an inert backdrop to the city but rather an

${ }^{23}$ Guy Beiner, Remembering the year of the French, pp. 156-67, 208-75; Guy Beiner, 'Disremembering 1798 ? An archaeology of social forgetting and remembrance in Ulster', History and Memory, xxv, no. 1 (Spring/Summer 2013), pp. 9-50, at pp. 16-21.

${ }^{24}$ Pierre Nora, 'Between memory and history: les lieux de mémoire’, Representations, xxvi (1989), pp. 7-24; M. Christine Boyer, The city of collective memory: its historical imagery and architectural entertainments (Cambridge, MA., 2001), pp. 322, 343. Other studies that have influenced this piece are: Dolores Hayden, The power of place: urban landscape as public history (London, 1995); Brian Graham, In search of Ireland: a cultural geography (London, 1997); Katharina Schramm, 'Landscapes of violence: memory and sacred space', in History and Memory: Studies in Representations of the Past, xxiii, no. 1 (2011), pp. 5-22; Gary A. Boyd and David Linehan (eds), Ordnance: war + architecture \& space (Farnham, 2013); Quentin Stevens, 'Cities and memory: a history of the role of memorials in urban design from the Renaissance to Canberra', Planning Perspectives (pub. online 17 Feb. 2019).

${ }^{25}$ Carsten Paluden-Müller, 'When memory takes place', in Marie Louise Stig-Sørensen and Dacia ViejoRose (eds), War and cultural heritage: biographies of place (Cambridge, 2015), pp. 261-67. 
agent for 'social processes' and a 'bearer of meaning in its own right'. ${ }^{26}$ In tracing these memories and representations this study also follows Astrid Erll and Ann Rigney's helpful concept of 'memorial dynamics'. ${ }^{27}$

The urban legacy of the Maamtrasna murders must be understood within an extensive international and comparative literatures on 'difficult' heritage, studies of demolition, the political power of ruins, and the afterlives of buildings and spaces. Echoing the legacy of British prisons in Ireland after the formation of the Free State, Sharon MacDonald, Gavriel D. Rosenfeld and others have analysed how the 'difficult' architectural heritage of Nazi Germany was demolished or repurposed after the Second World War. ${ }^{28}$ Similarly, William Logan and Keir Reeves present a series of international case-studies on how the legacy of former prisons has been managed as 'places of pain and shame'. ${ }^{29}$ For Jhennifer A. Amundson, architectural demolition represents more than a physical change; she sees it as a change in 'cultural values and temporal powers as

\footnotetext{
${ }^{26}$ Simon Gunn, 'The spatial turn: changing histories of space and place', in Simon Gunn and Robert J. Morris (eds), Identities in space: contested terrains in the Western city since 1850 (Aldershot, 2001), pp. 1-14, at p. 3; Leif Jerram, 'Space: a useless category for historical analysis?', History and Theory, lii, no. 3 (Oct. 2013), pp. 400-19.
}

${ }^{27}$ Astrid Erll and Ann Rigney, 'Introduction: cultural memory and its dynamics', in Astrid Erll and Ann Rigney (eds), Meditation, remeditation and the dynamics of cultural memory (Berlin, 2012), pp. 1-14, at p. 2. ${ }^{28}$ Sharon MacDonald, Difficult heritage: negotiating the Nari past in Nuremberg and beyond (Abingdon, 2009), pp. 2-5, 52-79; Gavriel D. Rosenfeld, 'Architecture and the memory of Nazism in postwar Munich', German Politics \& Society, xvi, no. 4 (Winter 1998), pp. 140-59, at pp. 143-8; Inge Manka, 'A (trans) national site of remembrance: the former Nazi Party rally grounds in Nuremberg', German Politics \& Society, xxvi, no. 4 (Winter 2008), pp. 113-33.

${ }^{29}$ Chapters on former prisons in William Logan and Keir Reeves (eds), Places of pain and shame: dealing with "difficult heritage" (Abingdon, 2009), pp. 163-230. 
the old is swept away in favor of the new. ${ }^{30}$ The question of how to memorialise the burial plot at Galway jail complicates any straightforward agenda of demolition (how does one demolish what is beneath the ground?). Furthermore, the question of whether to preserve some small fragment of a former prison site, associated with suffering and national memory, is taken up in Joan Beaumont's study of Changi prison in Singapore, where Australian soldiers were imprisoned by occupying Japanese forces in 1942-45. She notes the 'multiple and shifting identities' of the prison and that its memory is a 'dynamic interactive process' between many different actors. ${ }^{31}$ The outcome of demolition - ruins - have a political agency of their own and form a crucial part of the memorial dynamics of a site. Daniela Sandler and Andreas Schönle note the importance of ruins in contemporary heritage debates in Germany and Russia. ${ }^{32}$ In Galway, the ruins of the old jail played different roles in the site's history at different times.

${ }^{30}$ Jhennifer A. Amundson, 'Demolition', in R. Stephen Sennott (ed.), Encyclopedia of 20th-century architecture (3 vols, London, 2004), i, 668-70, at p. 668.

${ }^{31}$ Joan Beaumont, 'Contested trans-national heritage: the demolition of Changi Prison, Singapore', International Journal of Heritage Studies, xv, no. 4 (2009), pp. 298-316, at pp. 300, 306. Other studies that have been influential here are: Jean Baudrillard, 'Requiem for the Twin Towers', in Jean Baudrillard, The spirit of terrorism and other essays (trans. Chris Turner, London, 2003), pp. 35-48; Adam Sharr and Stephen Thornton, Demolishing Whitehall: Leslie Martin, Harold Wilson and the architecture of White Heat (Farnham, 2013), pp. 35-62.

32 Daniela Sandler, Counterpreservation: architectural decay in Berlin since 1989 (London, 2016), pp. 197-230; Andreas Schönle, 'Ruins and history: observations on Russian approaches to destruction and decay', Slavic Review, lxv, no. 4 (Winter 2006), pp. 649-69; Andrew Herscher, 'In ruins: architecture, memory, countermemory', Journal of the Society of Architectural Historians, lxxiii, no. 4 (Dec. 2014), pp. 464-9. 
Finally, this study sees many interesting parallels in the growing literature - especially strong in the Global South - on the 'afterlives' of contentious spaces, particularly in urban contexts. ${ }^{33}$

\section{I: Representations}

Galway jail, by the time Browne assumed office in 1937, had already accrued a rich palimpsest of meanings and memories in political and literary writing and can be seen as a classic Lefebvrian 'represented space'. ${ }^{34}$ Many - but not all - of these related directly to Maamtrasna and to Myles Joyce. Before considering what Browne knew of Joyce and how he viewed the case from the 1930s, it is necessary to trace the wider representations of the jail site. In the drama of the Maamtrasna incident, the jail featured on several occasions: it was where Joyce and the other nine men arrested were brought by steamer down Lough Corrib for an initial inquiry. ${ }^{35}$ At the trials in Dublin, the judge referred in precise and grim spatial detail to Galway jail as he set out the fate that awaited Joyce:

'That you be removed to Her Majesty's Jail in Galway, and that on Friday, the 15th day of December next, you be taken to the common place of execution, within the walls of the said prison, and that you there and then be hanged by the neck until you be dead, and

\footnotetext{
${ }^{33}$ Susana Draper, Afterlives of confinement: spatial transitions in postdictatorship Latin America (Pittsburgh, PA., 2012); and the special issue on the afterlives of monuments in South Asia in South Asian Studies, xxix, no. 1 (Mar. 2013), pp. 1-167, including Cherry, 'The afterlives of monuments', pp. 1-14. See also the forthcoming workshop, 'The prison \& the city: spaces of incarceration, practices of exclusion, and public communication', Center for Urban History of East Central Europe, Lviv, Ukraine, 3-4 Oct. 2019.

${ }^{34}$ Henry Lefebvre, The production of space (trans. Donald Nicholson-Smith, Oxford, 1991), p. 33.

35 Waldron, Maamtrasna, p. 52; Kelleher, Maamtrasna, pp. 61, 65-6.
} 
that your body be buried within the precincts of the prison in which you were confined after your conviction, and may the Lord have mercy on your soul. ${ }^{36}$

Upon arrival back in Galway, hundreds of people waited at the railway station to see the convicted men, who were escorted in open horse-drawn carriages to the jail. ${ }^{37}$ Waldron recalls from folklore sources that tradesmen in the town refused to erect the wooden scaffolding for the gallows in one of the jail's yards, and that the work was instead undertaken by men from Dublin..$^{38}$ The executions were in turn witnessed by a very small number of officials and journalists (though many wrote of the events afterwards); in terms of a public audience Kelleher notes that severe weather on the morning of 15 December 1882 reduced the number of spectators who stood outside the jail. ${ }^{39}$ What they saw - when the botched hangings were eventually concluded - was a black flag raised over the jail. As the Freeman's Journal recalled, 'the prison yard wore a usual mournful and impressive aspect, the walls, and trees still retained the garb of which and over the snow-covered walks, muffled and silent officers walked noiselessly'. ${ }^{40}$ Thereafter Joyce and the other two men were buried quickly inside the jail, their urban grave in

\footnotetext{
36 Waldron, Maamtrasna, pp. 108-23; Kelleher, Maamtrasna, pp. 117-28.

${ }^{37}$ Freeman's Journal, 27 Nov. 1882; Kelleher, Maamtrasna, p. 134.

38 Waldron, Maamtrasna, p. 134.

${ }^{39}$ Evening Telegraph, 15 Dec. 1882; Galway Express, 16 Dec. 1882; Kelleher, Maamtrasna, pp. 137-42. The journalists included Andrew Dunlop and Frederick J. Higginbottom, both of whom published autobiographical accounts of the hangings afterwards. The private nature of the events contrasts with the vivid description of a public hanging in at Galway jail in the 1830s, published, curiously, in anon., The sportsman in Ireland, with his summer route through the highlands of Scotland, by a cosmopolite (2 vols, London, 1840), ii, 24-6. See also Brendán Mac Suibhne, The end of outrage: post-famine adjustment in rural Ireland (Oxford 2017), pp. 56-7.

${ }^{40}$ Freeman's Journal, 11 Jan. 1883.
} 
stark contrast to the tranquil rural cemetery where lay buried some members of the murdered Joyce family. ${ }^{41}$ As Kelleher has discovered, the high drama of the executions soon found their way into popular ballads such as 'Lamentable lines on the execution of the Maamtrasna murderers'. ${ }^{42}$ Joyce's rapid transformation from prisoner to martyr spurred legends of his reappearance as a ghost within the jail. The chapbook Full report on the appearance of the ghost of Myles Joyce in Galway Jail (1883) gives the 'thrilling item of news from Galway':

'Myles Joyce ... has "appeared" within the precints [sic] of the prison. The apparition, it seems, was kept a secret at first by the officials, believing it to be some delusion or joke. But all doubts were set at rest when on last night two soldiers, who were on guard within the prison, were followed for some time by a tall mystic figure which ... approached them, actually touched the rifles, and vanished. ${ }^{43}$

These legends hint at the enormous public interest in the case that continued through the 1880s. The Illustrated Police News of London, for example, ran a follow-up story on the ghost of Joyce, and, in 1884, he made one more appearance - this time in a sketch in United Ireland (Fig. 2

\footnotetext{
${ }^{41}$ Waldron, Maamtrasna, pp. 45 (illus.), 149-54.

${ }^{42}$ Kelleher, Maamtrasna, pp. 168-70 and plate XIII; Margaret Kelleher, “'Ta me ag imeacht”: the execution of Myles Joyce and its afterlives', in Fionnuala Dillane, Naomi McAreavey and Emilie Pine (eds), The body in pain in Irish literature and culture (New York, 2016), pp. 99-115, at pp. 110-12. The ballad is in the Broadsheet ballad, National Folklore Collection, UCD.

43 Anon., Full report on the appearance of the ghost of Myles Joyce in Galway jail (Dublin, 1883), p. 1 (copy in N.L.I.). This text is taken almost entirely from Freeman's Journal, 11 Jan. 1883.
} 
[portrait]) - where he is shown saint-like next to the gallows, denouncing a terrified George Bolton, the crown solicitor, and Spencer. ${ }^{44}$

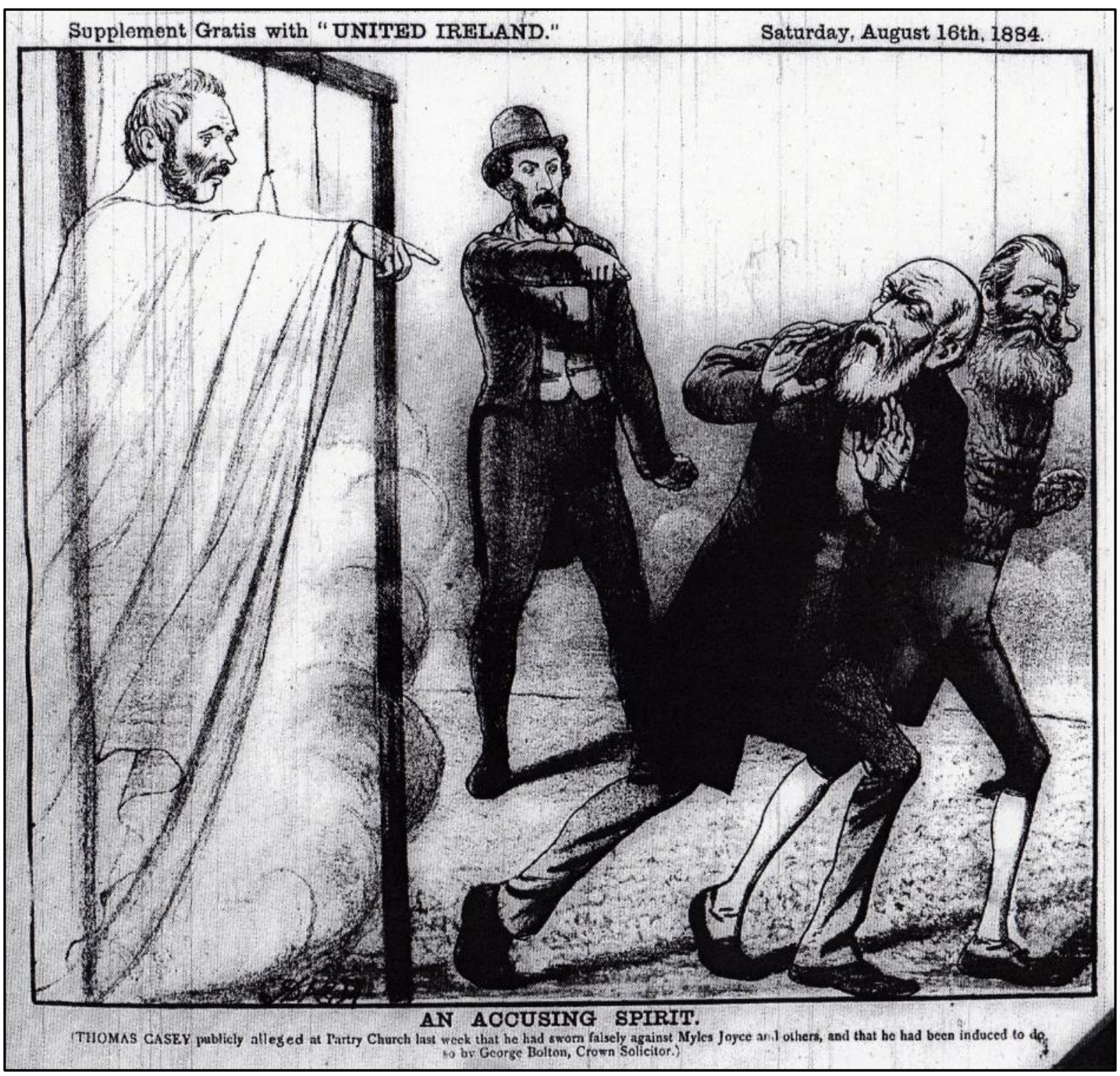

Fig. 2. Myles Joyce, 'An accusing spirit', from United Ireland, 16 Aug. 1884

${ }^{44}$ Illustrated Police News, 27 Jan. 1883; United Ireland, 16 Aug. 1884; Waldron, Maamtrasna, p. 213 (illus.); Kelleher, “Ta me ag imeacht”, p. 112; Kelleher, Maamtrasna, pp. 168-70. 
In the turbulent political atmosphere of 1880s Ireland, Joyce's case was instrumentalised by nationalists as a visceral example of the failures of British rule in Ireland. Harrington led the charge in his The Maamtrasna massacre: impeachment of the trials (1884). It included a vivid description of Joyce's protests to the jail officials as he was led to the gallows. ${ }^{45}$ Other contemporary actors knew Galway jail even more intimately: both the writer and activist Wilfrid Scawen Blunt (18401922) and the Land League M.P. William O’Brien (1852-1928) spent time there as prisoners in the 1880s. Blunt spent a month in Galway jail in the winter of 1888 following an outlawed Home Rule meeting in Woodford, Co. Galway. While he later wrote with some fondness of the 'oldfashioned, easy-going' conditions of his imprisonment (compared with his later spell in Kilmainham), he nonetheless found the dark and cold cells trying, and for solace took enthusiastically to studying the Bible. ${ }^{46}$ His incarceration garnered much publicity at the time, to the extent that Lady Gregory admitted herself to the jail to sketch the cell where Blunt had been kept (and sent him poetry about the jail). In the streets around the prison and even in boats on the river, there were significant public protests in sympathy, often met by a heavy-handed police response. ${ }^{47}$ Blunt later wrote an account of his jail time in poems published as In vinculis [imprisonment] (1889), including the sonnet 'Farewell, dark gaol', and in his autobiographical The Land War in Ireland (1912). ${ }^{48}$ A year later, O'Brien spent three months in the jail, one of his many

${ }^{45}$ Timothy Harrington, The Maamtrasna massacre: impeachment of the trials (Dublin, 1884), pp. v-vi; Waldron, Maamtrasna, pp. 193-213; Murphy, Ireland's cæar, pp. 231-37ff.; Kelleher, Maamtrasna, pp. 151-74.

${ }^{46}$ James Mitchell, 'The imprisonment of Wilfrid Scawen Blunt in Galway: cause and consequence', Journal of the Galway Archaeological and Historical Society, xlvi (1994), pp. 65-110, at pp. 68-72, 78-9, 85. Blunt's Bible, which later passed into the ownership of Lady Gregory, is now kept in the Hardiman Library, NUI Galway.

${ }^{47}$ Ibid., pp. 73-83, 90-95.

${ }^{48}$ Wilfrid Scawen Blunt, In vinculis (London, 1889), p. 15; Wilfrid Scawen Blunt, The Land War in Ireland (London, 1912), pp. 368-97; Mitchell, 'The imprisonment of Wilfrid Scawen Blunt', pp. 89-90, 99-100, 
stints in various Irish prisons, and during which time he wrote some of his Fenian novel When we were boys (1890). The Galway Town Commissioners, in an act of political solidarity during his incarceration, named after him a newly built bridge downstream of the jail. ${ }^{49}$

While Blunt and O'Brien fit easily into the mould of late nineteenth-century Irish political prisoners, they did not relate (or perhaps did not see the need to relate) their experience to the difficult legacy posed by Joyce's wrongful conviction and botched execution. ${ }^{50} \mathrm{By}$ contrast, Joyce arguably assumes a more prominent role in two literary works of 1906-7: indirectly in Lady Gregory's short play The gaol gate, and, much more explicitly, in James Joyce's essay 'Ireland at the bar'. Gregory's poem 'Without and within' (1888) may perhaps be seen as her first work on Galway jail - sent to Blunt during his imprisonment - but in The gaol gate she returned to the architectural scene of the jail gatehouse. ${ }^{51}$ The play centres on a mother from a remote mountainous area who attends the jail, is intimated by its 'terrible great height', and seeks to meet with her imprisoned son, who we learn is innocent and has been convicted by false

103, 107-8; James Mitchell, 'Wilfrid Scawen Blunt: a prisoner in Galway Gaol, 1888', The Mantle, viii, nos. 3-4 (Autumn/Winter 1965), pp. 88-97; Waldron, Maamtrasna, p. 52. Blunt appears not to comment on the Maamtrasna murders.

49 Wiliam O’Brien, When we were boys (London, 1890); Plaque on O’Brien's Bridge, Galway; Joseph V. O'Brien, William O'Brien and the course of Irish politics, 1881-1918 (London, 1976), pp. 70-72; James H. Murphy, 'William O’Brien's When We Were Boys: a new voice from old conventions', Irish University Review, xxii, no. 2 (Autumn/Winter 1992), pp. 298-304. O’Brien also wrote about the Maamtrasna incident - see United Ireland, 23 Dec. 1882; Kelleher, Maamtrasna, p. 171.

${ }^{50}$ For a study of female prisoners in Galway jail, see Geraldine Curtin, The women of Galway jail: female criminality in nineteenth-century Ireland (Galway, 2001).

${ }^{51}$ Lady Gregory, Seven short plays (London, c. 1909), 'The Gaol Gate’, pp. 173-85, 201-2; Mitchell, 'The imprisonment of Wilfrid Scawen Blunt in Galway', pp. 91-2. 
evidence through a legal system perceived to be foreign and unjust. She soon finds that he has already been hanged and buried inside the jail; his body will not be released and she and her daughter-in-law keen for him outside. ${ }^{52}$ Though Gregory included some notes in which she explained what inspired the play (and in which she makes no mention of Joyce's execution), The gaol gate has been interpreted by Waldron as a commentary on Maamtrasna, and Joyce's widow Bridget Joyce in particular, who in folklore accounts keened outside Galway jail for nine days after his execution..$^{53}$ The gaol gate was regularly performed through the revolutionary years and into the $1930 \mathrm{~s} .{ }^{54}$

James Joyce's short essay was a forthright condemnation of Joyce's execution. ${ }^{55}$ First published in Italian as 'L'Irlanda alla sbarra', it fashioned Myles Joyce as a 'bewildered old man, left over from a culture which is not ours, a deaf-mute before his judge', as 'a symbol of the Irish nation at the bar of public opinion.' Highlighting the failures of language interpretation at his trial, Joyce added, somewhat apocryphally, 'On the day the sentence was to be carried out, the square in front of the prison was packed with people who were keening and calling out prayers in Irish for the repose of [his] soul. ... Legend has it that even the hangman could not make

\footnotetext{
${ }^{52}$ Gregory, Seven short plays, pp. 173-85; Anna Pilz, 'Lady Gregory’s The Gaol Gate, Terence MacSwiney and the Abbey Theatre', Irish Studies Review, xxiii, no. 3 (2015), pp. 277-91, at pp. 278-81, 285; Dawn Duncan, 'Lady Gregory and the feminine journey: The Gaol Gate, Grania, and The Story Brought by Brigit, Irish University Review, xxxiv, no. 1 (Spring/Summer 2004), pp. 133-43.

${ }^{53}$ Gregory, Seven short plays, pp. 201-2; Waldron, Maamtrasna, pp. 145, 155; Joyce, State of freedom, p. 306; and an important note by Kelleher, Maamtrasna, pp. 170-3. Oral histories from the 1970s also recall that several women gathered to pray outside the jail the day before Joyce's execution (interview with Mrs. Lynskey, Bridge Street, Galway by Mr. Tom Kenny, Galway).

${ }^{54}$ Pilz, 'Lady Gregory's The Gaol Gate', pp. 282-7.

55 Waldron, Maamtrasna, pp. 155-6; Kelleher, Maamtrasna, pp. xx-xxi, 195-214.
} 
himself understood by the victim and angrily kicked the unhappy man in the head to force him into the noose. ${ }^{56}$ This essay was the most strident politicisation of the case since Harrington's era. ${ }^{57}$ Joycean scholars have also noted that references to the Maamtrasna murders can be traced in the trial scene of Finnegans Wake (1939). ${ }^{58}$

Galway jail's difficult legacy has been subject to continuous political representation since Joyce's execution. This only intensified in the revolutionary years, for example in Pádraig Pearse's story 'An bhean chaointe' [The keening woman], first published in 1916. Pearse includes references to Galway jail, and the story overall owes much to The Gaol gate, but also - as Waldron has argued - to the folklore history of Bridget Joyce's keening. ${ }^{59}$ During the War of Independence, many republican prisoners were kept and tortured in the jail, including Ned Lyons, who died soon-after in an asylum. ${ }^{60}$ In more recent decades, the journalist Robert Kee, in his preface to Waldron's Maamtrasna (1992), sees the 'blatant miscarriages of justice' of Joyce's era through the lens of the Northern Irish conflict and the treatment of the 'Maguire seven' and

\footnotetext{
${ }^{56}$ James Joyce, 'Ireland at the bar', in Kevin Barry (ed.), Occasional, critical, and political writing (Oxford, 2000), pp. 145-8, 325-6, at pp. 145-6; Jeanne A. Flood, 'Joyce and the Maamtrasna murders', James Joyce Quarterly, xxviii, no. 4 (1991), pp. 879-88; Kelleher, Maamtrasna, pp. 199, 201-2.

${ }^{57}$ Adrian Hardiman, Joyce in court: James Joyce and the law (London, 2017), pp. 51-90.

${ }^{58}$ Christine O’Neill-Bernhard, 'Symbol of the Irish nation, or of a foulfamed potheen district: James Joyce on Myles Joyce', James Joyce Quarterly, xxxii, nos. 3-4 (Spring/Summer 1995), pp. 712-21, at pp. 719-21; Kelleher, Maamtrasna, pp. 209-13.

${ }^{59}$ P. H. Pearse, The mother (An máthair) and other tales (Dundalk, 1916), pp. 57-88, at pp. 81-82, 85;

Waldron, Maamtrasna, p. 155.

${ }^{60}$ Conor McNamara, 'Connacht', in John Crowley, Donal O Drisceoil, Mike Murphy and John Borgonovo (eds), Atlas of the Irish revolution (Cork, 2017), pp. 600-07, at p. 603.
} 
the 'Guildford four', whose convictions he had campaigned to have overturned. ${ }^{61}$ Waldron steered clear of such overt politicisation but wrote powerfully of the 'heartbreak, drama and tragedy' of the case and of the burial plot near Galway cathedral from where Joyce's 'cry echoes still'. ${ }^{62}$ In recent years, Patrick Joyce, in The state of freedom (2013) argues plainly that 'the cradle of the British state engendered the grave of Myles Joyce'. ${ }^{63}$ The theme of injustice has also been taken up in recent Irish language and digital works on the case. ${ }^{64}$

How then did Browne, newly installed as bishop, understand the rich political legacy of the jail site? He was keenly interested in history and kept, for example, a file setting out important events in his own lifetime, copious news clippings from the revolutionary years, and copies of older texts on the history of Galway. He was aware of the difficult legacy of executions and burials in the jail, but also of his own historical importance as a Catholic bishop who would build a major new cathedral only a generation after the War of Independence. ${ }^{65}$ In his private

\footnotetext{
${ }^{61}$ Waldron, Maamtrasna, p. 7; Robert Kee, Trial and error: the Maguires, the Guildford pub bombings, and British justice (London, 1986); Irish Independent, 18 Oct. 1989.

${ }^{62}$ Waldron, Maamtrasna, pp. 52, 318. See also McAree, Murderous justice, pp. 199-200.

${ }^{63}$ Joyce, State of freedom, p. 307; Kelleher, Maamtrasna, pp. 170-3.

${ }^{64}$ Ó Cuirreáin, Éagóir; Fin Dwyer, 'The Maamtrasna murders' (3-part podcast, Irish History Podcast, released 1-14 Nov. 2016); Colm Bairéad and Seán Ó Cuirreáin, 'Murdair Mhám Trasna' (TG4 documentary, first broadcast 4 Apr. 2018).

${ }^{65}$ Galway Diocesan Archives (G.D.A., Bishop Browne papers, B/11/15-139. See in particular: manuscript notes made by Browne detailing events in his life which let up to his consecration, c. 19201937, n.d., n.s. (G.D.A., B/11/15); newspaper cuttings of important events in Browne's life (G.D.A., B/11/27); notes on local history (G.D.A., B/11/109, B/11/125). It is unclear if Browne was aware of Higginbottom's 1934 memoir which included a vivid account of Joyce's execution - see The vivid life: a journalist's career (London, 1934), pp. 38-44; Kelleher, Maamtrasna, p. 172.
} 
papers he penned a memo on the Maamtrasna murders - not previously published - that mixed fact and legend:

Joyce who was murdered was a sheep-stealer - terrible offence in those mountains.

Twelve men led by John Casey entered the house and took out Joyce who slept naked.

They fired at him but bullets had no effect as he was double-ribbed: of medium stature but enormous strength. One of the women recognised Casey and said in Irish don't harm us John, whereupon he sent the men back into the house to kill all ... only one small boy escaped. Casey made an alibi for himself by drinking whiskey that night with Lord Leitrim's bailiff. Miles [sic] Joyce was innocent but was hanged with two men in Galway Jail. ${ }^{66}$

Browne's focus on the exaggerated - and perhaps exotic - aspects of the masculinity of John Joyce is curious here, as is his omission of any comment on the controversies of Myles Joyce's trial. For Browne there was little straightforward about the case. It involved complicated and bitter family feuds. Even Joyce, the innocent figure, had been involved in the years before his execution in activities that Browne, with his keen interest in private property rights, would have seen as criminality: trespass, the taking of animals, the disturbance of land boundaries ${ }^{67}$ Clearly it was not a simple case of a heroic martyr wronged by an imperial power - the incident grew out

\footnotetext{
${ }^{66}$ Anon. [Michael Browne], 'Maamtrasna murders', n.d. [c. 1941] (G.D.A., B/4/2).

${ }^{67}$ Anon. [Michael Browne], 'The proposed town plan for Galway: by a citizen', n.d. [May 1945] (G.D.A., B/12/32); Kelleher, Maamtrasna, p. 26.
} 
of, as Waldron has commented, a 'valley of vendettas' ${ }^{68}$ This complexity later influenced how Browne negotiated the legacy of the jail site.

\section{II: The death of the prison}

In the late 1930s it was not a foregone conclusion that Galway jail would in time become the site for a new Catholic cathedral. The jail shut in May 1939 and until this time what to do with its difficult legacy was a purely academic matter. Indeed, throughout the 1930s the diocese's official position was to build the new cathedral on a different site near (William) O’Brien's Bridge. ${ }^{69}$ The jail's decline was part of a broader national story of falling conviction rates (and a changed policing culture) after the revolutionary years. ${ }^{70}$ In April 1925, for example, there were 773 men and 86 women in the Free State's prisons; ten years later, this had fallen to 507 men and 72 women. The national cell occupancy rate fell from $44 \%$ to just $33 \%$. There was clearly spare capacity within the system, and, furthermore, most prisoners were concentrated in the large Mountjoy and Portlaoise jails and not in the smaller provincial prisons. In 1935 there were just 6

\footnotetext{
${ }_{68}$ Waldron, Maamtrasna, p. 27; Kelleher, Maamtrasna, pp. 26, 72-6. The initial press coverage of the murders was universally hostile, with the Freeman's Journal describing Myles Joyce and the other nine men as 'the biggest devils in the city' - see Freeman's Journal, 23 Aug. 1882.

${ }^{69}$ Butler, 'Catholic power and the Irish city', forthcoming; Richard J. Butler, 'Building and rebuilding Galway since 1820', forthcoming; G.D.A., B/6/1, B/6/2, B/6/22.

${ }^{70}$ Chairman, General Prisons Board, to Secretary, Department of Justice, 30 Jan. 1925 (N.A.I., H248/2); Mary Rogan, Prison policy in Ireland: politics, penal-welfarism and political imprisonment (London, 2011), pp. 20 53; Mark Finnane and Ian O'Donnell, 'Crime and punishment', in Eugenio F. Biagini and Mary E. Daly (eds), The Cambridge social history of modern Ireland, 1740 to the present (Cambridge, 2017), pp. 363-82, at pp. 376-78.
} 
people in total in Galway jail, 34 in Sligo, and 6 in Waterford. ${ }^{71}$ The Department of Justice used these figures to justify shutting smaller jails, and by 1940 there were only five active prisons in the state.

After a tumultuous nineteenth-century, Galway jail entered a long period of windingdown and neglect. As early as 1925 the General Prisons Board considered reducing its status. Civil servants mined the train timetables to ascertain if it would be possible to move prisoners to and from other nearby jails in time for Galway court sittings (they suggested not). They noted that many of the 14 staff employed were elderly and could soon be pensioned. One of these, the medical officer R. J. Kinkead, had been in post long enough to remember Joyce's execution. ${ }^{72}$ The plan to reduce the jail to 'minor' status (meaning prisoners could only be kept there for a week or so) was parked at this stage, owing in no small part to the strenuous opposition of the Urban District Council and Chamber of Commerce, for whom the jail's future was a more economic concern. ${ }^{73}$ Nonetheless within three years the government again attempted (unsuccessfully) to downgrade the jail by moving its small number of female prisoners elsewhere, arguing that 'there is at times not sufficient work to occupy fully the three women officers on the Prison Staff. ${ }^{74}$ By 1934 the jail housed only men and for relatively short sentences. ${ }^{75}$ With so

\footnotetext{
${ }^{71}$ N.A.I., H248 and JUS/90/16/183. The figures for April are generally representative for any given year and replicate the trends in Finnane and O'Donnell, 'Crime and punishment', p. 378.

${ }^{72}$ Memo, General Prisons Board, 16 June 1925 (N.A.I., JUS/90/16/262).

${ }^{73}$ Secretary, Department of Justice, to Vice Chairman, General Prisons Board, 22 Aug. 1925; and Secretary, Galway Urban District Council, to Minister for Justice, 13 Aug. 1925 (N.A.I., JUS/90/16/262); Connacht Tribune, 11 July 1925.

${ }^{74}$ Secretary, General Prisons Board, to Secretary, Department of Justice, 25. Jan. 1928 (N.A.I., JUS/90/16/262).

${ }^{75}$ Saorstát Éireann: annual report on prisons for the year 1934, p. 17 (N.A.I., JUS/90/16/161).
} 
many smaller jails closed, and often demolished to make way for housing, hospitals, factories, or Garda stations, it must have been clear by the mid-1930s that the writing was on the wall for the jail's future: its visiting committee diligently continued their work but saw fewer and fewer prisoners, and in March 1935 just one man (who, they duly noted, 'expressed satisfaction with his treatment'). ${ }^{76}$ It was at this stage that alternative futures for the jail site began to be proposed.

The legacy of Maamtrasna was curiously absent from these early discussions. As far back as 1931 a member of the Ballinasloe Mental Hospital Committee suggested that the jail, which he said 'would soon be empty', could serve as an auxiliary mental hospital for the county: the response from a medical doctor that for the patients 'it would make a nice seaside residence all right' was met with laughter, but the idea progressed no further. ${ }^{77}$ In 1934 (and again in 1937) a group attached to Galway's Renmore Barracks and the Office of Public Works proposed building a commemorative Volunteer's Hall on part of the now-disused female prison, something that was quickly rejected by the Department of Justice. ${ }^{78}$ In 1936 the Galway Urban District Council asked for 'a defined portion of the jail which would be walled off from the rest of the premises' for new Municipal Buildings, including a new Town Hall. The scheme quickly expanded to include a new 'Fire Brigade Station and Public Abattoir' but then progressed no

\footnotetext{
${ }^{76}$ Chief Warder, Galway Prison, to Secretary, Department of Justice, 11 Mar. 1935 (N.A.I.,
} JUS/90/16/5). Browne was keenly aware of the number of recently closed provincial prisons and sought information from friends regarding valuations and sales - see Browne to Monsignor Joyce, 30 Mar. 1940 (G.D.A., B/6/4).

${ }_{77}$ Connacht Tribune, 15 Aug. 1931.

${ }^{78}$ Chief Warder, Galway Prison, to Secretary, Department of Justice, 1 Sept. 1934; and Secretary, Department of Justice, to Secretary, Office of Public Works, 28 Sept. 1934 (both N.A.I., JUS/90/16/262); Secretary, Department of Defence, to Secretary, Department of Justice, 9 July 1937 (N.A.I., JUS/90/16/263). 
further. ${ }^{79}$ Finally, in 1938, Seán McEntee, the Minister for Finance, considered using the jail site for new offices for the Revenue Commissioners; writing to Patrick J. Ruttledge, the Minister for Justice, he argued, 'the site is at present wasted on a jail' but added 'as I understand that certain other interests are also anxious to obtain the jail site, I am enlisting your co-operation in securing that we get priority'. ${ }^{80}$ McEntee was here referring to Browne's desire to secure the site for a future cathedral, but Ruttledge in reply hoped that 'as the grounds are fairly extensive ... it may be possible to accommodate both parties' ${ }^{81}$ However, this relationship soon became more adversarial when Michael O'Flaherty of the Galway Corporation commented publicly on the future of the site in January 1939:

'No city liked to lose big institutions, but no one would very much regret the passing of Galway prison, of which some Galway people had unpleasant memories in regard to the years between 1916 and 1922. ... Get a hold of it first for nothing. Some other people may step in and ask for it. ${ }^{82}$

O'Flaherty here neglected to mention any earlier 'unpleasant memories' but hints at how local politicians understood the emerging competition to secure the large urban site. Browne, in turn, wrote to Ruttledge, once he was made aware of McEntee's plans, and those of the Corporation, and said that 'I hope that I shall not be swamped by my numerous and powerful competitors. ${ }^{93}$

\footnotetext{
${ }^{79}$ S. de Bhilmot to Secretary, Department of Justice, 30 Apr. 1936 and 24 May 1937; S. de Bhilmot to Private Secretary, Minister for Justice, 9 June 1937 (all N.A.I., JUS/90/16/263).

${ }^{80}$ Seán McEntee to Patrick J. Ruttledge, 16 Dec. 1938 (N.A.I., JUS/90/16/263).

${ }^{81}$ Ruttledge to McEntee, 30 Dec. 1938 (N.A.I., JUS/90/16/263).

${ }^{82}$ Connacht Tribune, 14 Jan. 1939.

${ }^{83}$ Browne to Ruttledge, 13 Feb. 1939 (N.A.I., JUS/90/16/263).
} 
But these competitors quickly fell away, especially once McEntee received an unfavourable report on the cost of demolishing the buildings and he decided to build elsewhere. ${ }^{84}$

Ruttledge announced in March 1939 that Galway jail would close the following May, with its few remaining prisoners to be moved to Limerick and Sligo. ${ }^{85}$ In the local newspapers, rumours (however unlikely) continued to circulate, including that the jail wall was sufficiently large 'to permit of a G.A.A. pitch being laid out on the site'. ${ }^{86}$ By this time Browne was determined to use the site for a much more monumental purpose, which would inevitably lead to him having to negotiate the difficult legacy of the prison. In late 1938 he decided to pursue the jail site instead of the smaller site at O’Brien's Bridge after studying the report from a committee of four priests who were tasked with monitoring pedestrian and car movements across the city's bridges over three Sunday mornings in November. These men counted the number of people walking and driving east and west between parishes; they backed up their arguments with tables and appendices. The jail site, they argued, had a 'slight advantage' in terms of its catchment area. ${ }^{87}$ Further confirmation came from a parishioner who wrote anonymously to Browne, conscious of the jail's legacy; he said: 'just think ... what a beautiful building could be erected upon that ground which is now enclosed by that ghastly $20 \mathrm{ft}$ stone wall. ${ }^{88}$

\footnotetext{
${ }^{84}$ George P. Fagan to Secretary, Department of Finance, 18 Feb. 1939 (N.A.I., JUS/90/16/263).

${ }^{85}$ Galway prison closing order, 1939 (28 Mar. 1939). Available at http://opac.oireachtas.ie/AWData/Library3/Library2/DL056754.pdf); Irish Press, 1 May 1939. ${ }^{86}$ Connacht Tribune, 8 Apr. 1939.

${ }^{87}$ William H. Byrne \& Son to Browne, 17 Nov. 1938 (G.D.A., B/6/3); Patrick Davis, et al., memo, 1 Dec. 1938 (G.D.A., B/6/3); Browne to Ruttledge, 13 Jan. 1939 (N.A.I., JUS/90/16/263). ${ }^{88}$ Anon. ['A devout Roman Catholic'] to Browne, 9 Jan. 1939 (G.D.A., B/6/3).
} 
Browne, aware of the rich political history of the site, sought to instrumentalise its memory in his campaign to secure possession from Galway County Council, who inherited the site from central government. What they proposed to do with it was the subject of a debate tabled for 13 April $1940 .{ }^{89}$ In anticipation, Browne wrote to all of the priests in the diocese urging them to lobby their local councillors to make sure that the vote went in his favour:

'It is quite possible that some of the County Councillors may think we have enough churches in the country or that a playing-field or factory would be more useful. It is not possible at a meeting to explain the spiritual advantages of a Cathedral or to overcome prejudices. ${ }^{90}$

In return, some of his parish priests warned that 'all precautions should be taken to dispel' any other purchaser - including by issuing a letter to the newspapers. ${ }^{91}$ Browne decided to give a public speech at the council, where he presented the old jail site as a lieu de mémoire, referencing not only the prison's political legacy but also much older tropes of Catholic dispossession, renewal, and triumph:

I am advised that the jail site would make a most suitable emplacement for a Cathedral: it is spacious, with dignified and beautiful surroundings, not hemmed in with unsightly buildings but with magnificent approaches and views on each side. Forty years ago my predecessors should not have dreamed that this site would become available for a Cathedral. Today under native Irish government a jail is not required in County Galway.

\footnotetext{
${ }^{89}$ Galway County Council minutes, 1932-48, for 13 Apr. 1940 (pp. 481-2) (G.C.A., GC1-05(d)).

${ }^{90}$ Browne, letter addressed to all priests in the Galway diocese, 30 Mar. 1940 (G.D.A., B/6/4).

${ }^{91}$ The parish priest, Oughterard, to Browne, 5 Apr. 1940 (G.D.A., B/6/4).
} 
What finer tribute to our people or better justification of the long struggle for selfgovernment? Now that the site has become available, I submit to you that there could be no more noble or more fitting use than to erect on it a Cathedral in thanksgiving to God who sustained our people in their days of trial. A Cathedral replacing a jail is the most perfect symbol of the triumph of a people who were proscribed for being Irish and Catholic...The building of a Cathedral will [also] provide considerable employment to stonemasons and workers for many years. ${ }^{92}$

Browne struck the right note and the site was handed over for a nominal sum by unanimous consent of the councillors. ${ }^{93}$ But the council's administrative staff were more careful, aware that a cathedral was an enormous project and that the fundraising for it may take years or even decades, and in the meantime the site would stay derelict and vacant. They inserted a clause stipulating that if the cathedral's walls were not more than 12 feet high by a certain date, the site would revert to council ownership - to which the bishop reluctantly agreed. ${ }^{94}$

For Browne, ownership of the jail site brought its rewards and its challenges: now the jail's history and memory - as well as more practically its yards, burial ground, gate, and high walls would have to be carefully negotiated. The rewards were relatively straightforward; they were tangible, physical, and visual. First of all, a 'handing over the keys' ceremony was staged in

\footnotetext{
${ }^{22}$ Browne, draft copy of letter to Galway County Council, n.d. [Apr. 1940]; Browne to Galway County Council, 9 Apr. 1940 (both G.D.A., B/6/4). Browne's use of the phrase 'in their day of trial' was likely a deliberate pun here, and was an alteration from his draft letter.

${ }^{93}$ Galway County Council minutes, 1932-48, for 13 Apr. 1940 (pp. 481-2) (G.C.A., GC1-05(d).

${ }^{94}$ Browne to Clement O’Flynn, 3 Sept. 1940; O’Flynn to Fr. O’Dea, copied to Browne, 17 Jan. 1941 (both G.D.A., B/6/4).
} 
front of the jail gate in May 1941. This was at Browne's request, who thought that 'such a ceremony would be an interesting and historical one..$^{95}$ As the council had already given him the keys, he had to quietly return these some days before the event for the official ceremony. ${ }^{96}$ The press photographs show the group of men respectfully holding their hats in their hands as the bishop 'received' the keys; in the background is the austere wooden wicket gate and ashlar stone quoins of the gateway as in Gregory's play. Ownership of the jail site encouraged Browne to take further steps to ensure that no nearby building work could obscure his future cathedral. The diocese paid $£ 400$ for a vacant plot near the canal, to the west of the jail, 'in order to prevent the erection of buildings thereon which [could] present an unharmonious appearance ${ }^{97}$ More immediately, he arranged for the jail buildings to be demolished. ${ }^{98}$ This was an acute historical moment in the city's history, and the bishop was none too aware of it. His personal papers contain 32 photographs of men taking down the old prison. ${ }^{99}$ Evidently, he was keen to photograph and document the eradication of the jail. The photos show ashlar blocks being knocked by hand, and groups of men heaving and pulling at cell walls (Fig. 3 [landscape]). The local newspapers chronicled the vanishing of a landmark building - with the Connacht Tribune adding that 'save for the grim outer wall, Galway Jail has now vanished almost completely'. ${ }^{100}$ The work also provided valuable employment during the lean 'Emergency' years - on which

\footnotetext{
${ }^{95}$ Browne to O’Flynn, 2 May 1941 (G.D.A., B/6/4).

${ }^{96}$ O’Flynn to Browne, 13 May 1941 (G.D.A., B/6/4).

${ }^{97}$ Browne to John C. Conroy \& Son, 10 May 1941 (G.D.A., B/6/4). Browne also purchased several jail warder's cottages for the same purpose, see Browne to MacDermot \& Allen, 10 May 1941 (G.D.A., B/6/4).

${ }^{98}$ G.D.A., B/6/7.

${ }^{99}$ G.D.A., B/6/8.

100 Connacht Tribune, 21 Mar. 1942.
} 
Browne was lobbied by the city mayor. ${ }^{101}$ By the middle of 1943 , the site was reduced to a high wall containing a great pile of loose masonry - the wall kept to secure the site during future building work. ${ }^{102}$ The demolition of the jail followed in the wake of the disappearance from the Irish urban landscape of other nineteenth-century prisons - for example in Monaghan, Ennis, Tullamore, and Waterford. ${ }^{103}$ In all these cases photographs taken at the time documented the visual effects of a changing social order and of the new power relationships, perhaps akin to the vanishing of so many 'big houses'. ${ }^{104}$ A photograph from Monaghan in the 1930s shows the ruined jail framed by a gleaming new county hospital under construction; in Tullamore young men stood atop heaps of rubble proudly posing with a tricolour; and in Waterford the demolition of the jail could not happen soon enough followed a major tragedy when the stockpiling of turf against its walls caused a partial collapse onto nearby cottages in March 1943, killing 9 people and injuring 17 more. ${ }^{105}$

${ }^{101}$ Browne to O’Dea Solicitors, 10 Feb. 1941 (G.D.A., B/6/14); Browne to O’Flynn, 3 May 1941 (G.D.A., B/6/4). Browne was also asked if the jail buildings could be kept as a tourist attraction to raise money for the St. Vincent de Paul during the Galway Races - see William Glennon to Browne, 16 June 1941 (G.D.A., B/4/2).

102 Photographs of the demolition of Galway jail, n.d. [c. 1941-43] (G.D.A., B/6/8); M. Burke, 'Galway Gaol demolition: summary of account, 1942-1943', n.d. (G.D.A., B/6/4); The Mantle, ii, no. 2 (Spring 1959), p. 36; Mitchell, 'The prisons of Galway', p. 18.

${ }^{103}$ Ennis Urban District Council papers for the lease and sale of portions of Ennis gaol, c. 1932-37 and c. 1951-52 (N.A.I., ENV/3, 2013/94/41, 469); Clare Champion, 28 May 1960.

${ }^{104}$ Dooley, The decline of the big house in Ireland. ${ }^{105}$ Monaghan: photograph of Monaghan gaol and hospital, c. 1938 (Monaghan County Museum); Tullamore: Michael Byrne, 'The county courthouse at Tullamore and the making of a county town', Journal of the Offaly Historical and Archaeological Society, i (2003), pp. 108-25, at p. 123; Waterford: Irish Independent, 5 and 26 Mar. 1943. 


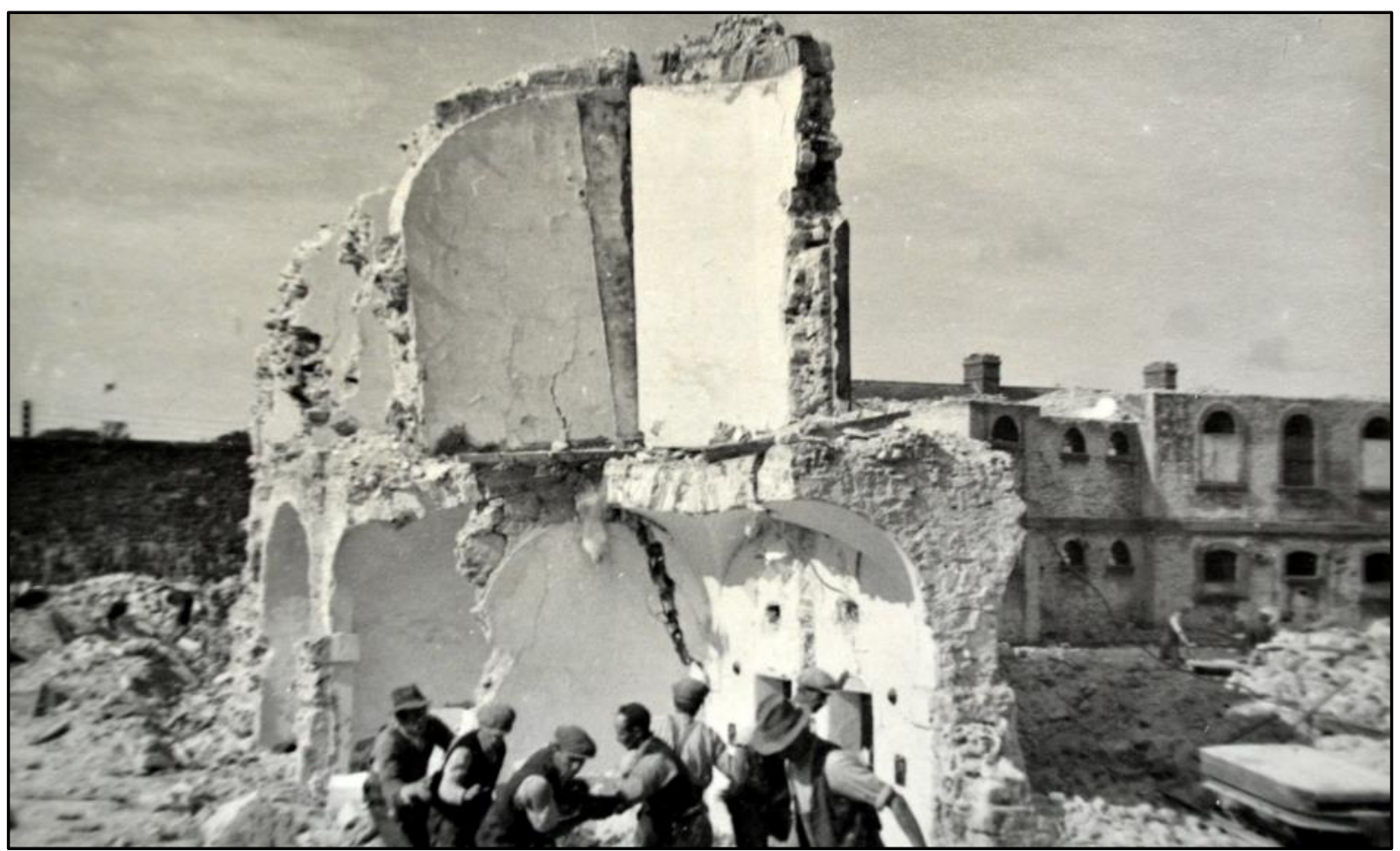

Fig. 3. Men demolishing Galway jail during the 'Emergency' years, c. 1941-43.

From Galway Diocesan Archives, Bishop Browne papers, B/6/8.

Watching the jail's cell blocks vanish was unproblematic compared with how to negotiate the burial plot in one of its yards. Browne recognised that this would have to be preserved in some way and could not simply be obliterated. When he arranged for the jail's demolition, he explicitly stated that the burial plot and its adjoining walls were 'not to be taken down or interfered with in any way' - and even included a plan drawing showing in red the places that were 'not to be touched'. ${ }^{106}$ He asked the County Council and the Department of Justice for information on the history of the burials in the jail, recalling that O'Brien had written a book while held prisoner there. ${ }^{107}$ In reply, Clement O'Flynn, the county manager, wrote:

\footnotetext{
106 Agreement of 11 July 1941 between Michael Browne and Malachy Burke; anon., 'Diagramatic [sic] plan of Galway jail', n.d., n.s. (both G.D.A., B/6/7).

107 Browne to O’Flynn, 14 June 1941 (G.C.A., 109/38/72 (CC/CC/13/3/0001)).
} 
'I think there should be no difficulty in locating the place where executed persons were buried in the Jail premises. My recollection is that when I visited the place first I saw a small portion of the ground in one corner railed off with an iron railing, and that there were some small iron or wooden crosses over the graves. If the long grass inside the railing is cut the crosses will probably be found. ${ }^{108}$

Browne's interest in the burial plot was shared by Seánín Bán Ó Conabuí (John Conoboy), the husband of Joyce's daughter Máirín. ${ }^{109}$ He raised the issue indirectly with his T.D., Mícheál Ó Móráin, in the summer of 1943, once the demolition work was complete, and asked if it would be possible to exhume Joyce's body and give him a proper burial in Connemara:

'Now the said Myles Joyce was executed with two other men. [He] was an innocent man that never took part in the murders, but his life was sworn away on perjured evidence. The old jail has been taken over by the Bishop now for building a new Cathedral on the spot, and it seems that the bodies of all the executed must be transferred to some other place, for reinternment. So the relations of Myles Joyce would like it if his remains was handed over to them to have him buried among their own at Churchfield Tourmakeady. ... [He] said that he did not see why should not an Irish Government hand over the remains of an innocent man, to his own to be buried amongst his own.... We can give more particulars about Myles Joyce's innocence, if required. We have his last words in

\footnotetext{
108 O'Flynn to Browne, 3 July 1941 (G.D.A., B/6/4).

109 Waldron, Maamtrasna, p. 318; Kelleher, Maamtrasna, p. 193.
} 
the Irish language, he never spoke a word of English [and] it is a piteous declaration of innocence. ${ }^{, 110}$

While exhumation might have appeared a convenient solution - and surely one that Browne would have accepted - it was turned down by Gerald Boland, the Minister for Justice, who argued that 'the remains of all executed persons are buried in unmarked graves within the precincts of the gaols in which they are executed, [and] it would be impossible, after the lapse of 61 years, to identify the remains of any executed person. ${ }^{, 11}$ The graves would thus remain at Nun's Island - a decision that continues to have an impact today on the site's legacy.

Browne capitalised on the historical legacy of the jail site as a 'most perfect symbol of the triumph' of Catholic Ireland in his public speech to the council; in private correspondence he saw alternative - perhaps surprising - ways in which the burial plot could be employed to more practical and financial advantage. Upon taking possession of the site for the nominal sum of $f_{1} 10$, the Revenue Commissioners sought to value the site for capital gains tax and Browne was shocked by a local auctioneer's initial high estimation $(£ 2,344) .{ }^{112} \mathrm{He}$ argued that it was worth only a fraction of this and focused on the question of class and jail's legacy as a place of execution and burial - eliding the particularities of Joyce's case:

'I do not think that the sale value would be very much for houses if it be recalled that the bodies of executed criminals are buried there. ... The market value as sites for residence would be very low, if indeed anything at all. For the whole prison was not an ordinary

\footnotetext{
${ }^{110}$ Miceál Gibbons to Mícheál Ó Móráin, 21 Aug. 1943 (N.A.I., JUS/90/16/408).

111 Gerald Boland to Mícheál Ó Móráin, 2 Sept. 1943 (N.A.I., JUS/90/16/408).

112 Browne to O’Flynn, 2 May 1941; O’Dea Solicitors to Browne, 19 May 1941 (both G.D.A., B/6/4).
} 
prison, but one where criminals were executed and buried. At one end of the prison they were executed and at another place they were buried. Now the memory of this remains and will remain, and I submit that no woman or children would willingly live in a house built on such ground with such weird and ghostly associations. No Town Council would dream of putting a building scheme on such a site for the working classes; how can you then expect that the well-to-do will pay up to $£ 250$ for such sites? I therefore submit that the only value the jail site has is as a public park. It has never been known that a site where criminals were executed has been used in Ireland for a residence. ${ }^{, 113}$

The auctioneer gave in and reduced his valuation to just $f, 500$, writing that 'it is to be expected that people who could afford to build the better class houses would choose more cheerful surroundings. ${ }^{114}$ In the marketplace of memories, particular historical values could rise and fall at different moments and in different contexts - of the criminals, the martyrs, those rightly and those wrongly hanged in the jail's long century and a half of operation.

\section{III: Cathedral rises}

There was always, as might be expected, a disjuncture between the political and cultural imagination of the jail and the stone-and-mortar reality of a large derelict site in the centre of the large town. With the jail buildings reduced to a heap of rubble, this divergence only further increased (Fig. 4 [landscape]). ${ }^{115}$ The long hiatus in construction - between 1943 and 1957 -

\footnotetext{
113 Browne to Thomas MacEnri, 23 May 1941 (G.D.A., B/6/4).

114 Thomas McEnri, 'Galway prison grounds: certificate of market value', n.d. [May-June 1941] (G.D.A., $\mathrm{B} / 6 / 4)$.

${ }^{115}$ Curtin, Women of Galway jail, p. 104.
} 
arose from Browne's need to undertake such extensive fundraising, especially in the United States. The delay heaped pressure on him to account for the increasingly overgrown state of the jail site and it soon became an object of public ridicule. At a meeting of the Galway Corporation in 1952, one councillor joked that 'I'd nearly bet a penny that the Cathedral will be built as soon as [our] Municipal Buildings', which, the local newspaper reported, was received 'amid laughter'. ${ }^{116}$ Undeterred, Browne once more mobilised the jail's memory in his efforts to raise almost half a million pounds - equivalent to the annual wages of around 1,700 people at the time. ${ }^{117}$ Working with the Irish Embassy in Washington, President Seán T. O’Kelly, and the archbishop of Boston, Cardinal Richard Cushing, Browne toured America attending functions, giving talks, and seeking donations from the Catholic Irish-American community; he received a handsome response. ${ }^{118}$ He penned letters for distribution to friendly priests that invoked the site's history as a place 'where Irishmen had suffered imprisonment and even death'. ${ }^{119}$ Back at home, Taoiseach Éamon de Valera added a new layer of potential historical associations by proposing that the cathedral could be a 'National Thanksgiving Memorial' for Ireland's 'safety through the war' - along the lines, he argued, of the Basilica of Sacré-Cœur in Paris - and even suggested that Browne could organise a nationwide collection in the way that 'the Anti-

116 Galway Observer, 20 Dec. 1952.

117 Michael Browne, The new cathedral of Galway: its origin, purpose and description (Galway, c. 1957), pp. 10-12. For the cathedral fundraising effort, see the regular updates in the diocesan magazine, The Mantle, from its establishment in 1958 onwards. Average annual salary of $£ 300$ in the 1950 s taken from Edward Nevin, Wages in Ireland, 1946-62 (Dublin, 1963), p. 18.

118 G.D.A., B/6/50, B/6/55, B/6/56; Irish Press, 16 Dec. 1960; The Mantle, iv, no. 1 (Spring 1961), pp. 24 7.

119 Browne, letter concerning fundraising for distribution, n.d. [probably 1958] (G.D.A., B/6/50). 
Conscription Fund was raised in 1918, ${ }^{120}$ Browne abandoned the idea, fearing pushback from other bishops about a 'National Memorial' in 'any place outside Dublin'. ${ }^{121}$ Nonetheless he gave a prominent place to the site's history and memory in a promotional booklet published around 1957. Alongside a photograph of the jail gate he noted its 'many famous prisoners', highlighting two in particular - O'Brien and Joyce - and adding that 'executions by hanging took place in the jail, and some of those hanged were in popular belief innocent, as in the case of the Maamtrasna murders'. ${ }^{122}$

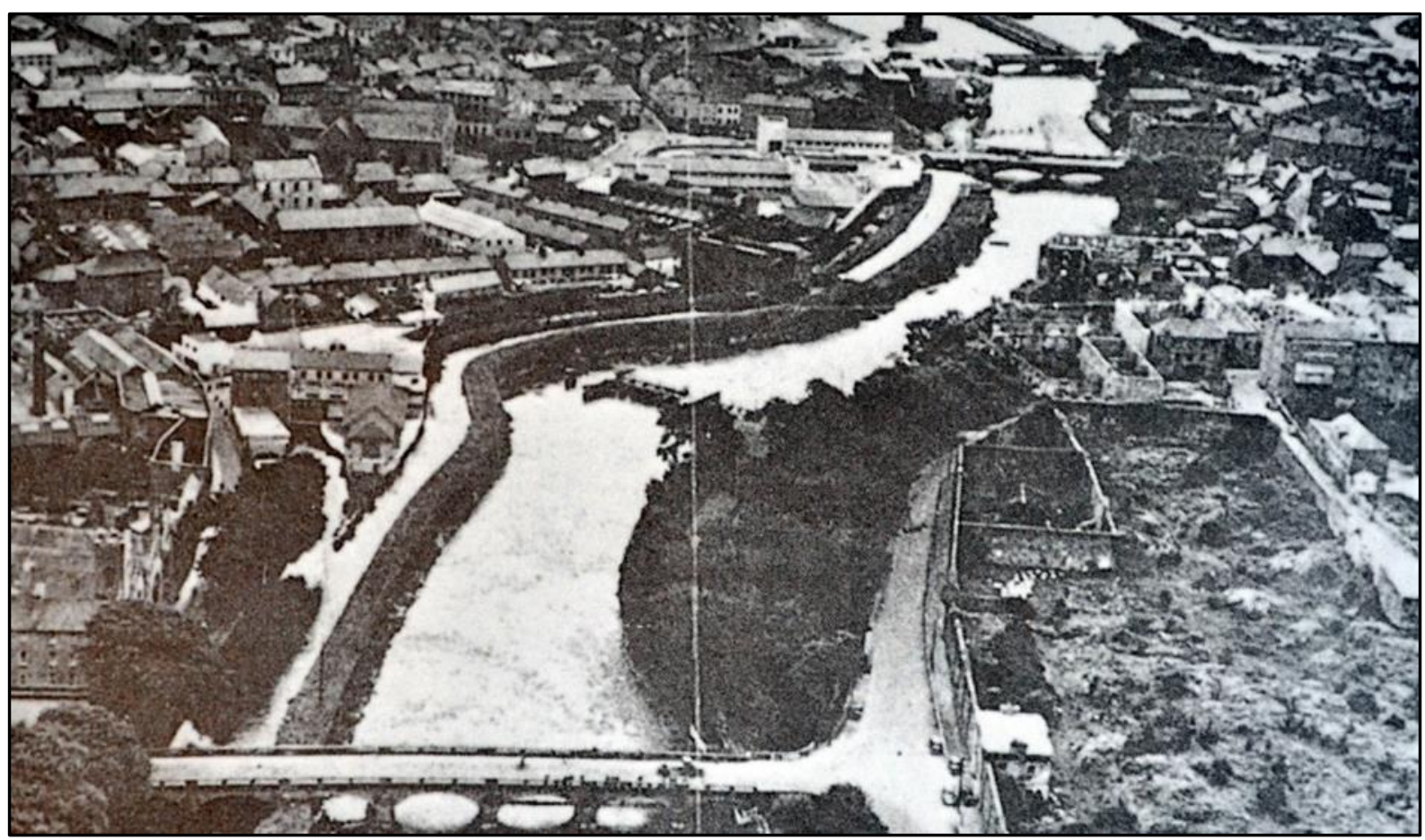

Fig. 4. Galway jail in ruins, c. 1955. From Geraldine Curtin, The women of Galway jail: female criminality in nineteenth-century Ireland (Galway, 2001), p. 104. Reproduced courtesy of Geraldine Curtin.

120 Text of speech given by Éamon de Valera, Galway, 27 Oct. 1957 (N.A.I., TSCH/3/S16327A); de

Valera to Browne, 27 Nov. 1957 (G.D.A., B/6/60).

${ }^{121}$ Browne to de Valera, 21 Nov. 1957 (N.A.I., TSCH/3/S16327A).

122 Browne, New cathedral of Galway, pp. 5-7. 
There was an everyday reality of the site's dereliction, in which ordinary people - in the long wait for the construction of the cathedral to begin - interacted with the former jail. The most regular visitors to the site through the 1950s were young boys who trespassed and scoured the rubble for valuable metals. ${ }^{123}$ A mother wrote to the diocese in April 1950 apologising for her son's transgressions (and those of his friends) and offering to do whatever was required to keep him from gaining a criminal record. ${ }^{124}$ Some years later another teenage boy, on a bicycle, was arrested weighed down (conspicuously, presumably) by 40kg of lead pillaged from the site; he was sent to a reformatory for five years. ${ }^{125}$ These children experienced the jail not as a site of major political events but as a forbidden urban playground - and the local newspapers suggest that there were many such derelict sites in Galway where children enjoyed the thrill of urban exploring through the 1940 s and 1950 s. ${ }^{126}$

The blessing of the foundation stone in 1957 offered an opportunity to reconnect the physicality of the site with its historical associations. The guests of honour were O'Kelly, de Valera, and the archbishop of Armagh, Cardinal John D’Alton. ${ }^{127}$ Coordinating the planning of the event - and the erection of temporary altars and canopies - was the cathedral's architect,

\footnotetext{
${ }^{123}$ Some of the building materials were offered for sale in the mid-1940s but much remained discarded inside the jail walls - see Connacht Tribune, 2 Mar. 1946.

124 T. Canavan to Fr. Spelman, 25 Apr. 1950; Canavan to Browne, 26 Apr. 1950 (both G.D.A., B/6/9).

125 Connacht Sentinel, 16 Feb. 1957.

${ }^{126}$ For another example at Middle St. in Galway, see Connacbt Tribune, 14 Sept. 1940. The demolition of the old workhouse and its replacement by the Galway Regional Hospital in these years was yet another large derelict/ruined/construction site; see Irish Builder and Engineer, xcii, no. 1 (7 Jan. 1950), p. 18; Paul Larmour, Free State architecture: Modern Movement architecture in Ireland, 1922-1949 (Kinsale, 2009), pp. 94-5. ${ }^{127}$ Irish Independent, 28 Oct. 1957; Browne, text of speech [presumably at foundation-stone laying ceremony], n.d., n.s. (G.D.A., B/6/60).
} 
John J. Robinson. Preparing the site took many months, not least in the removal of so much rubble and vegetation. ${ }^{128}$ The ceremony was staged in the main yard, well away from the burial plot; the piles of masonry at the edges served as useful vantage points for the public to watch proceedings. Robinson arranged for the altars to be placed in alignment with the main gatehouse, and just as in 1941 a 'handing over the keys' photograph was staged in front of its increasingly vandalised wooden doors - this time Browne with the building contractors. ${ }^{129}$ In general the bishop and architect saw eye to eye but the proposed act of 'cutting the first sod' on the new building's foundations - something which must have raised eyebrows so close to a mass grave -, and of the use of the Irish language - another sensitive matter not unrelated to Joyce's case -, caused Browne to write somewhat caustically to Robinson that:

'There is no liturgical ceremony for the cutting of the first sod and it would be entirely beneath the dignity of the Cardinal to ask him. ... I do not see any reason why a large block of granite or limestone could not be procured beforehand and placed in position to be blessed. ... Please cancel all the arrangements you have made about flag-poles, amplification and banner - welcome to Galway etc. - ... all these matters can be taken care of in Galway. In regard to the banner with the inscription "Welcome to Galway", this is the Capital of the Gaeltacht and the Irish language is in use here. ${ }^{130}$

Browne's speech - given not without some irony in English - was fittingly triumphalist for the occasion and resonated with the Connacbt Sentinel, which reflected on the legacy of the

\footnotetext{
${ }^{128}$ John J. Robinson, architectural plan showing arrangement for the laying of the foundation stone; Browne to Robinson, 3 Aug. 1957 (both G.D.A., B/6/60).

129 Madeleine Lyons (ed.), Building a business: 150 years of the Sisk Group (Dublin, 2009), p. 67.

${ }^{130}$ Browne to Robinson, 31 July 1957 (G.D.A., B/6/60).
} 
"imprisoned men whose "crime" was that they aspired to freedom for their country, freedom to develop its own way of life according to its Catholic tradition. ${ }^{131}$ The ceremony, and the publicity and fundraising booklet that followed soon after, allowed the public to see Robinson's design for the first time. Architecturally the cathedral has been subject to strident criticism for its conservative, traditionalist style - both at the time and since. ${ }^{132}$ The detail of this debate is not relevant here except the need to point out that Browne genuinely desired the cathedral to be 'Irish' in some way, reflecting his broader interest in the history and political and cultural memory of the site. ${ }^{133}$ Upon receiving initial designs from Robinson in 1951, Browne asked all the priests in his diocese for comment. One asked if the main entrance could be revised to make it 'unmistakably of Galway, Ireland. As it stands, I could imagine myself finding it anywhere in American or Australia. ${ }^{, 134}$ Browne collated dozens of these letters and formed a reply to Robinson; in it he questioned why 'there was nothing distinctively Irish' about the design and asked that the main doorways should be of a 'Celtic type'. His position was that 'this cathedral is for Galway and should bear some mark of the place and history'. ${ }^{135}$ In return Robinson promised

${ }^{131}$ Browne, text of speech [presumably at foundation-stone laying ceremony], n.d., n.s. (G.D.A., B/6/60); Connacht Sentinel, 29 Oct. 1957.

132 Irish Builder and Engineer, xcix, no. 20 (5 Oct. 1957), p. 787; Ian Nairn, 'Ecclesiastical all-sorts', The Observer, 24 Apr. 1966; Galway Advertiser, 13 Aug. 2015. The design also received praise - see John T. Murray to Browne, 10 Sept. 1966 (G.D.A., B/4/42).

${ }^{133}$ Ellen Rowley, 'Hidden histories: Galway cathedral: the bishop as architect', Arcbitecture Ireland, no. 298 (Mar./Apr. 2018), pp. 37-9; Butler, 'Building and rebuilding Galway since 1820', forthcoming. ${ }^{134}$ Martin McDonough to Michael Browne, 24 Oct. 1951 (G.D.A., B/6/13(1)); correspondence regarding the cathedral's design (G.D.A., B/6/5, B/6/13(1)). 135 Browne to Robinson, 17 Nov. 1951 (G.D.A., B/6/13(2)). 
to revise the design - which it appears he did to some extent - and promised Browne that he would make it 'more Irish in feeling. ${ }^{136}$

As construction proceeded, Robinson's cathedral slowly emerged above the high walls of the old jail - a visually and metaphorically powerful spectacle that caught the attention of many local observers. To mark the shift the Galway Observer continued its long-running 'Galway in the Eighties' series - mostly focused on Land War events - with reprints of articles about incarcerations and executions in the old jail, including the hanging of Patrick Walsh for the 'Letterfrack murders' in $1881 .{ }^{137}$ This kind of journalism served as a collective reminder of the memories of the jail's dark past. Furthermore, Browne's newly established diocesan magazine, The Mantle, commented in almost every issue on the city's changing urban landscape with dozens of photographs and an article on Blunt's imprisonment; the cathedral, it proclaimed, is 'rising in its majesty over the jail walls'. ${ }^{138}$ When it finally came into clear view in the early 1960 s, the effect across the bridges of the city was striking, and the press photographers captured the contrast between the crisp stone of the new cathedral and the sombre, dark old gaol gate (Fig. 5 [landscape]). ${ }^{139}$ One of the last steps was to bulldoze the gate and its surrounding walls, marking the formal birth of the cathedral and the death of the prison. The transition was anticipated by comments that O'Kelly made at the blessing of the foundation stone: 'the old jail will disappear

\footnotetext{
136 Robinson to Browne, 2 Nov. 1951 (G.D.A., B/6/13(2)); Robinson, drawings for Galway cathedral, 1957-8 (Irish Architectural Archive (I.A.A.), Acc. 2006/45).

137 Galway Observer, 6 Mar. 1958. For articles in this series, see Galway Observer, 7 Jan. 1950, 21 Jan. 1950, 11 Feb. 1950, etc. 138 The Mantle, vi, no. 1 (Spring 1963), p. 13; and viii, nos. 3-4 (Autumn/Winter 1965), pp. 88-97. See also The Mantle, iii, no. 1 (Spring 1960), pp. 7-9, and v, no. 1 (Spring 1962), pp. 14-18.

${ }^{139}$ Connacht Sentinel, 15 Jan. 1963; Connacht Tribune, 14 Aug. 1965; various newspaper clippings (G.D.A., B/6/62, B/6/119); Lyons, Building a business, p. 42.
} 
and all the memorials of its unhappy history be obliterated. ${ }^{140}$ Local men, sensing the occasion, posed by the ruined gate (Fig. 6 [landscape]) while the newspapers showed women going about their day-to-day business as a heavy crane perched on the burial plot tearing down the execution yard's high walls (Fig. 7 [landscape]). ${ }^{141}$ This marked the final elimination of the site's nineteenthcentury built legacy, but not of course that of the graves beneath. It recalled the demolition of the jail buildings themselves back in the 1940s but also the many other provincial jails that had been taken down in other towns since the foundation of the state.

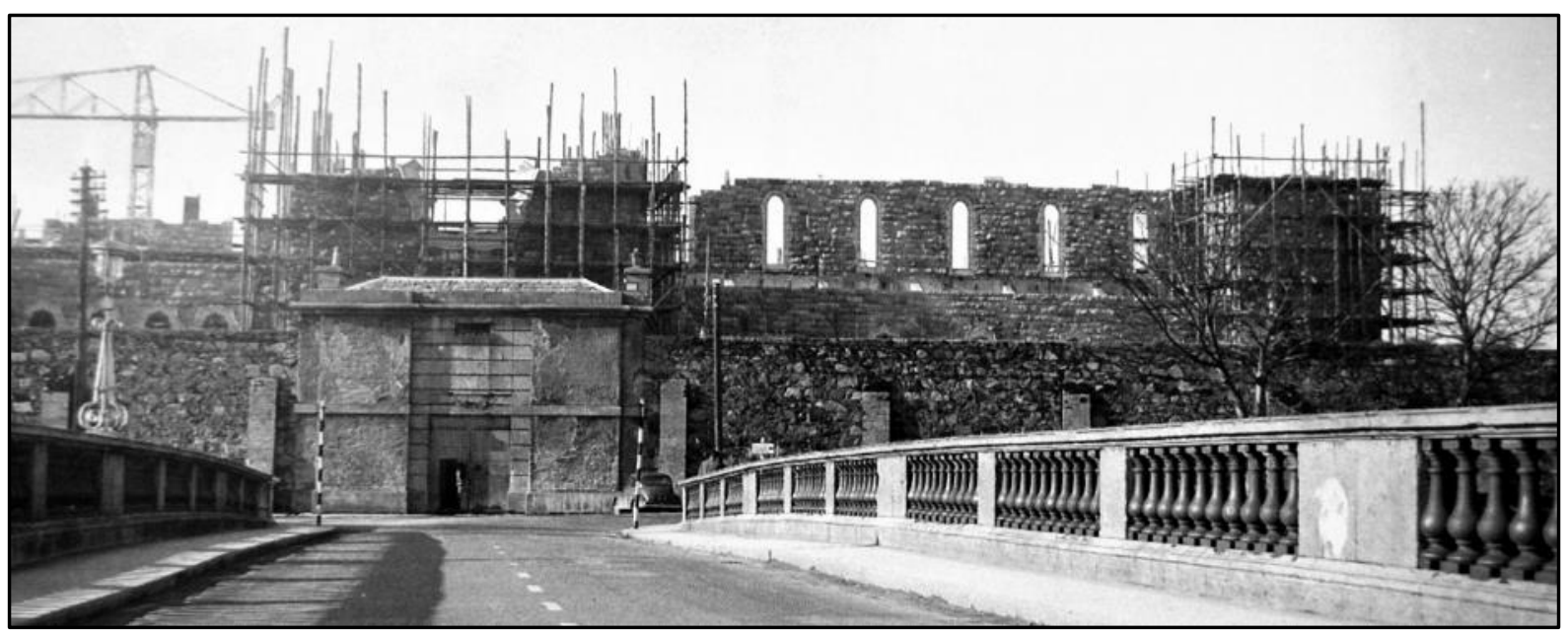

Fig. 5. Galway Cathedral rises over the gatehouse of the old jail, c. 1963. From Madeleine Lyons (ed.), Building a business: 150 years of the Sisk Group (Dublin, 2009), p. 42. Reproduced courtesy of the Sisk Group.

${ }^{140}$ Quoted in Browne, New cathedral of Galway, p. 6.

${ }^{141}$ Photographs by Donal Taheny (d. 2014), n.d. (Galway Public Libraries); Irish Press, 12 Jan. 1965. See also newspaper clippings (G.D.A., B/6/62). 


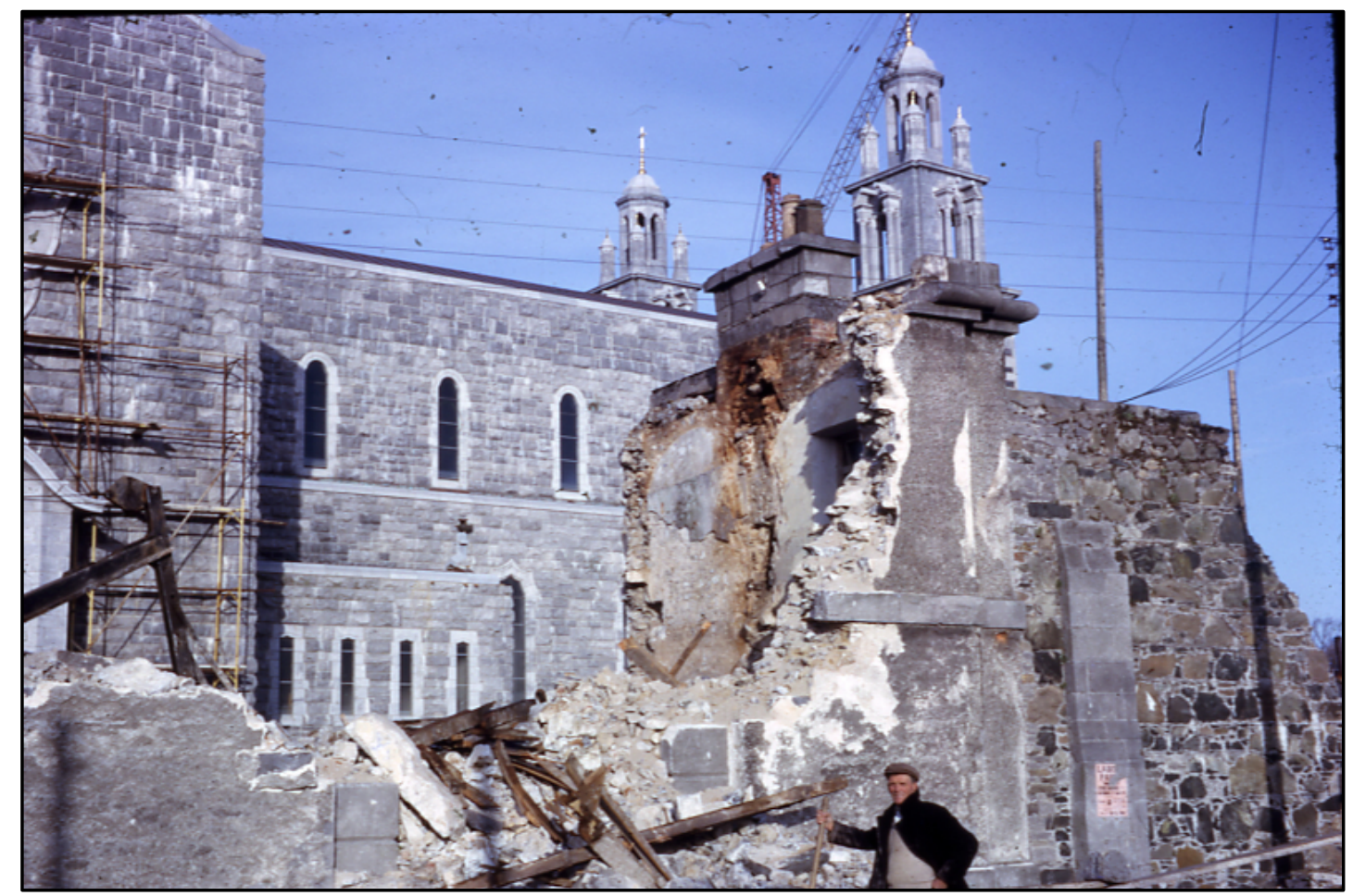

Fig. 6. A man poses by the ruined gatehouse, c. 1965. Photograph by Donal Taheny (d. 2014). Reproduced courtesy of Galway Public Libraries.

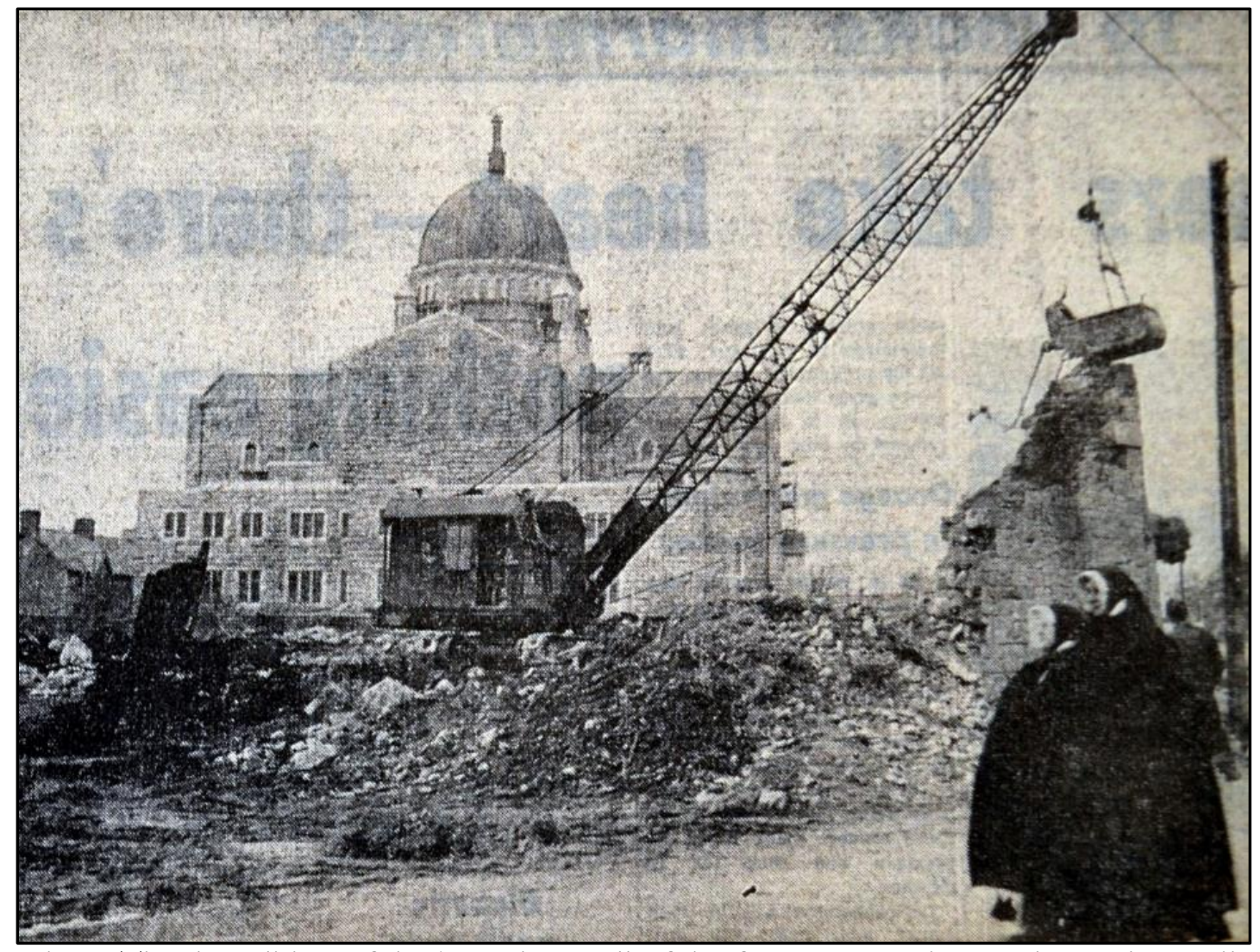

Fig. 7. The demolition of the boundary wall of the former execution yard at Galway jail. From the Irish Press, 12 Jan. 1965. 
The most potent opportunity for historical reflection came, of course, with the consecration of the cathedral on 15 August 1965, with Cushing, acting as the Papal Legate, the special guest. ${ }^{142}$ The event was a major moment in the history of the city with extra trains and buses put on for the estimated 12,000 people that watched the pageantry and processions. These recalled not just a particular tradition of Irish Catholic consecration ceremonies going back to the mid-nineteenth century, but also - considering the site's former history - an older and secular ritual of visiting assize judges being met at the county boundary and accompanied, with a guard of honour, to the courthouse and jail. ${ }^{143}$ Translated into a Catholic idiom, this took the form of Browne waiting in the priest's house at Gort, at the southern edge of his diocese, for Cushing's entourage to arrive from Wexford, with another stop at the city boundary where both men moved into an open state car with full police and army honours as 'huge crowds waited' to give Cushing a 'tumultuous Céad Míle Fáilte'. ${ }^{144}$ The procession, 'an unforgettable spectacle of colour and enthusiasm', which eventually made its way from Eyre Square to the cathedral on foot, included the highest officeholders of church and state: Cardinal William Conway, archbishop of Armagh, the Papal Nuncio Giuseppe Sensi, de Valera, and Seán Lemass. 'Throughout the city',

${ }^{142}$ Cushing was hardly enthusiastic about the visit, as he rather candidly told 'Irish hour' on Boston's WBOS radio station - see N.A.I., DFA/6/434, 2011/39/781.

${ }^{143}$ Niamh NicGhabhann, “'A development of practical Catholic Emancipation”: laying the foundations for the Roman Catholic urban landscape, 1850-1900', Urban History, xlvi, no. 1 (Feb. 2019), pp. 44-61; Terence M. Dunne, 'The law of Captain Rock', in Kyle Hughes and Donald M. MacRaild (eds), Crime, violence and the Irish in the nineteenth century (Liverpool, 2017), pp. 38-52, at p. 48; Katie Barclay, Men on trial: performing emotion, embodiment and identity in Ireland, 1800-45 (Manchester, 2019), pp. 70-71. ${ }^{144}$ Connacht Tribune, 21 Aug. 1965; Memo, draft itinerary for Cushing's visit, 5 Aug. 1965 (N.A.I., DFA/6/434 2011/39/781). 
the Connacht Tribune noted, 'candles glowed in windows many of which were decorated with miniature altars'. ${ }^{145}$

Cushing, predictably, framed the visual transition from jail to cathedral within a broader narrative of religious and political oppression, focusing on the spatialities of the site: 'down these roads and across these fields men suffered for the faith in a persecution as cruel and relentless as any in Christian history.' 'This very spot', he added, 'has been blessed with the tears and blood of those who gave up every earthly possession to keep their ancient faith. Cathedrals, we must remember, are built not only of steel and stone, they rise out of the sacrifice and suffering of a Christian people. ${ }^{, 146}$ Newspaper coverage by and large borrowed from biblical tropes of transition from darkness into light, with photographs showing the old jail gate and walls and references to Maamtrasna. The Connacht Tribune ran a short article which included a quote from one of the journalists - Frederick Higginbottom - who had witnessed Joyce's execution; his 'black and forbidding pile' of the old jail was juxtaposed with photographs of the new cathedral:

'The prison contains the bones of men whom many people in the West believed were wrongly executed. One of these was Myles Joyce [followed by a lengthy history of the Maamtrasna case].... Another man executed there and whom large numbers believed

145 Connacht Tribune, 21 Aug. 1965. The event received blanket coverage in the local and national newspapers - see for example: The Irish Catholic, 19 Aug. 1965; The Catholic Standard, 20 Aug. 1965; The Galway Observer, 21 Aug. 1965; and The Clare Champion, 21 Aug. 1965. For international coverage, see The Catholic Herald (UK), 20 Aug. 1965; The Florida Catholic, 20 Aug. 1965; and The Weekly Bulletin of the Department of External Affairs, no. 711 (7 Sept. 1965). Browne kept copies of all of these articles in his archive - G.D.A., B/6/106; Browne, Cathedral of Our Lady, pp. 12-14.

${ }^{146}$ Connacht Tribune, 21 Aug. 1965. 
innocent was Patrick Walsh, convicted of the Letterfrack murders. ... It is believed that Lady Gregory had Galway jail in mind when she wrote "The Gaol Gate.”"147

Even The Sun (UK) joined in with contrasting photos of the jail ('part of the past') and the cathedral ('today), ${ }^{148}$ and The Boston Sunday Herald Magazine gave its front cover to a colour photo of the new cathedral and commented that some older Galwegians may 'proudly recall the time they spent behind the walls of the jail during the Irish fight for independence'. ${ }^{149}$ In a nuanced reflection on the changing character of the site, an editorial in The Connacht Sentinel considered that 'in no part of the city has the change been so great and dramatic as at the place where the Cathedral stands. ... The old gloomy jail walls that cast their shadows...are gone'. ${ }^{150}$ A year later, Fr. Padraic O Laoi invoked Pearse on the $50^{\text {th }}$ anniversary of the Easter Rising, when, during his Easter sermon in the cathedral, he speculated on what he might have thought had he been alive to see a cathedral atop soil 'hallowed' by incarceration and execution:

'And I think Pearse would consider his efforts ... fully justified, vindicated, if he stood on the bridge beside this wonderful Cathedral today and gazed at the transformation. As he passed by to [his house at] Rosmuc, he must have often gazed at the drab, grey walls of Galway jail. I wonder did [he] foresee the substitution and transformation of a jail to this magnificent and inspiring temple of God - how the change would gladden his heart

\footnotetext{
147 Connacht Tribune, 14 Aug. 1965; Higginbottom, The vivid life, p. 40.

148 The Sun (UK), 13 Aug. 1965.

149 Peter Barnicle, 'A cathedral for Galway', The Boston Sunday Herald Magazine (15 Aug. 1965), pp. 37-8. 150 The Connacht Sentinel, 17 Aug. 1965; The Mantle, viii, nos. 3-4 (Autumn/Winter 1965), pp. 1-97, later reprinted as Galway Cathedral: 15th August, 1965: sowvenir of dedication (Galway, 1966); Browne, Cathedral of Our Lady, pp. 7-8; G.D.A., B/6/115.
} 
as it gladdened ours. For the soil on which this noble and artistic cathedral has been raised ... is a soil hallowed by the sufferings and blood of many of our kith and kin. ${ }^{151}$

More problematic was how to memorialise the burial plot. It required careful consideration from Browne, who as previously noted forbade any demolition work to the execution yard and burial site until the cathedral was almost complete. He planned a large carpark to be built over much of the southern half of the jail site, including over the burials (which would lie undisturbed beneath) and the former execution yard. ${ }^{152}$ In February 1965 he made it clear in building committee minutes that he "would like to have the graves of the people who were buried in the old jail marked in some way'; it was decided that 'the graves be marked by placing slabs over them. ${ }^{153}$ What exactly he meant by this is unclear but the Franciscan priest Fr. Robert O’Neill, writing at the time, commented on the end result (Fig. 8 [landscape]) and what he saw as a juxtaposition of tradition and modernity - a sombre Christian memorial in a surface-level tarmac carpark:

'Time marches on but not on foot! A good car-park is a need of today's church-goer. In this respect, Galway Cathedral is singularly fortunate. To the rear of the cathedral, wellmarked white lines guide to their chosen accommodation one hundred and fifty cars. But even here, modernity must yield to Christianity. ... Well within the parking lot, there is a raised plot. A concrete coping fringes it about. Along its length-wise, across it breadthwise, lies a flag-stoned cross. It is God's acre, the last resting place of those executed in

\footnotetext{
151 The Mantle, ix, no. 1 (Spring 1966), pp. 3-6; Pearse, 'The Keening Woman', p. 219.

152 The cathedral also has an entirely separate memorial to John F. Kennedy, who visited Galway before his assassination - see Galway Tribune, 25 Jan. 1964, G.D.A., B/6/119.

${ }^{153}$ Galway cathedral building minutes, 12 Feb. 1965 (G.D.A., B/6/95).
} 
Galway Jail. ... Close by, the Altar of Sacrifice has replaced the "Big Drop" of the executioner: a just Mercy has overcome an unmerciful justice. ${ }^{154}$

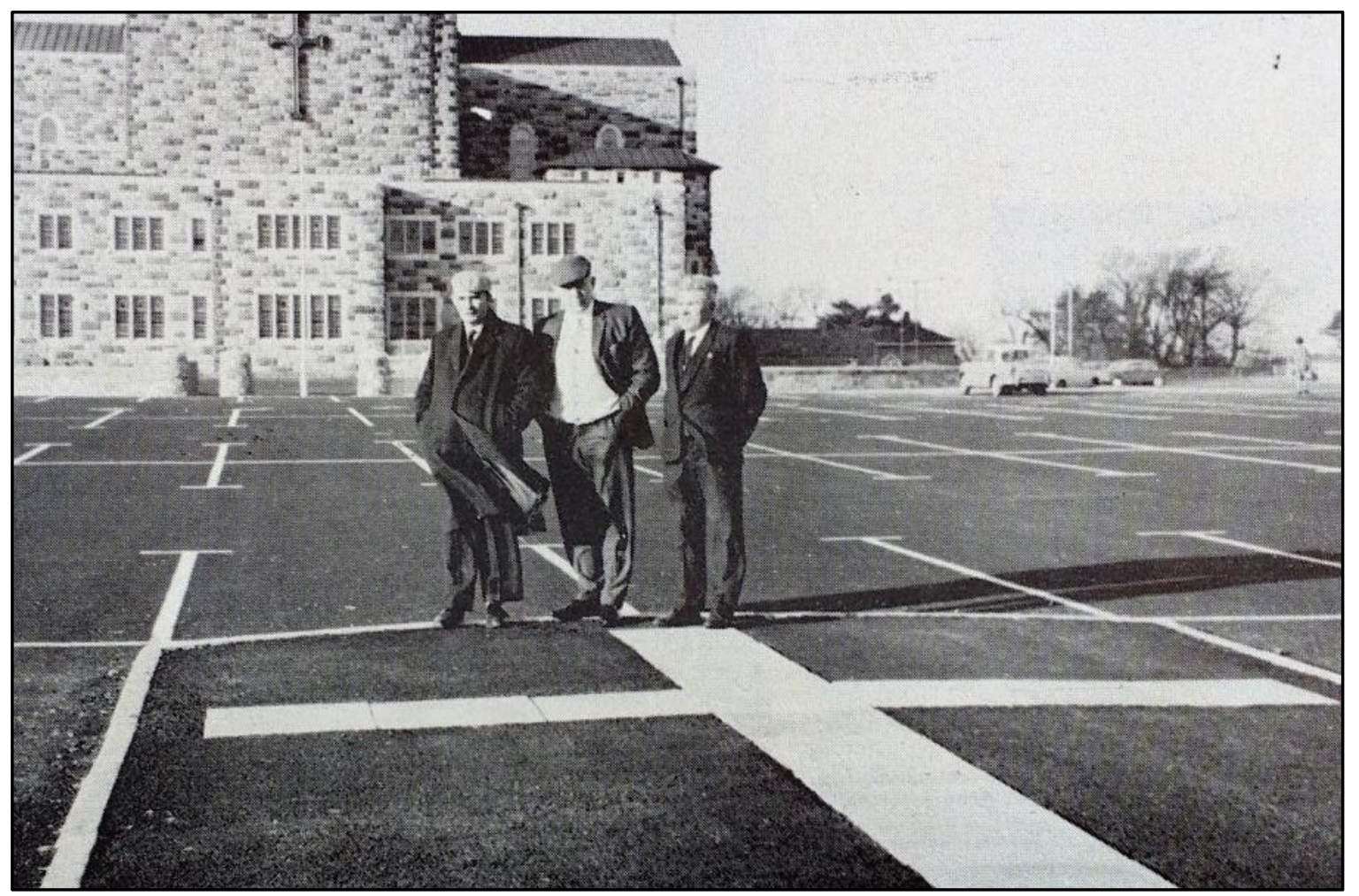

Fig. 8. Three men pose by the memorial on the site of the former execution yard and burial yard. From George Quinn (ed.), The opening and blessing of Galway cathedral, 15th August 1965 (Galway, 1966) (copy in Hardiman Library, NUI Galway), p. 2. The men pictured were responsible for the building and lighting of the car park.

The memorial's shortcomings became apparent almost immediately. As photographs from the time show, it was all too tempting for motorists simply to park their cars on it, and the 'flag-stoned cross', which Browne insisted was white - and which aligned with the grid of the white parking bays - too easily fooled drivers into seeing the memorial as little more than

${ }^{154}$ Unidentified publication by Robert O’Neill, O.F.M., 'Our new neighbour', pp. 259-60, at p. 260 (copy in G.D.A., B/6/106). 
auxiliary parking. ${ }^{155}$ This indignity was far from the 'wonderful proof of the victory of our people' that Browne proclaimed in his history of the cathedral project. ${ }^{156}$ Yet the unsatisfactory nature of the memorial persisted for many years and by the early 1990s it was woefully neglected. The City Tribune - which somewhat problematically referred to the memorial as that for 'Galway's executed criminals' - admitted that 'the site is at present surround[ed] by traffic cones with a sign saying: "Prison Grave Ground. No Parking."'. It added that 'cars had parked on the site which had been only marked by a cross', and quoted locals who complained that 'cars used to drive up over it' and that 'it was in an awful state'. ${ }^{157}$

As a result, the memorial was entirely rebuilt in 1993 into its present form: a crucifix of cut stone, raised above the surrounding tarmac, and with bollards to discourage adventurous parking. While it appears that the old memorial had no inscription, its replacement, in both Irish and English, is dedicated to 'all who died or were executed in the old gaol of Galway ... on which site the cathedral now stands'. The juxtaposition of crucifix, car park, and cathedral is now a popular photographic composition, and appears, for example, in dramatic lighting on the back cover of the cathedral's 2002 guidebook. ${ }^{158}$ This guidebook, however, contains no explanation for a visitor of the particular significance of Joyce's case, something that has been addressed in more recent campaigns, in publications marking the $50^{\text {th }}$ anniversary of the cathedral, and in Kelleher's new history. ${ }^{159}$ In 2016 a second plaque was added, specifically to commemorate Joyce

\footnotetext{
155 George Quinn (ed.), The opening and blessing of Galway cathedral, 15th August 1965 (Galway, 1966) (copy in Hardiman Library, NUI Galway). 156 Browne, Cathedral of Our Lady, pp. 8, 15.

${ }_{157}$ City Tribune, 20 Aug. 1993.

158 Anon., Galway cathedral: a visitor's guide (Galway, 2002) (photograph by Martin Hanley).

159 ‘Galway Cathedral, 1965-2015’, souvenir special pull-out, Connacht Tribune, 14 Aug. 2015.
} 
(in English only): "In memory of MYLES JOYCE An innocent man who was hanged on this site on the 15-12-1882 Aged 40 years. Rest in Peace”. The 2018 ceremony, attended by Higgins, was designed to bring full circle a journey of representation and negotiation of the spatial legacy of the Maamtrasna executions that began almost 140 years ago. Joyce's legacy has once again risen in prominence - historiographically, commemoratively, and tangibly - in the site's public representation. This can be attributed, more broadly, to shifts within recent Irish history writing: the rising tide of public history, the wealth of publishing by writers outside of academic institutions, and most of all the cultural and political revival of the Irish language in recent decades through increased government funding and the establishment in 1996 of a dedicated media outlet, Teilifís na Gaeilge (now TG4), which broadcast a well-received docu-drama about Joyce's execution around the time of his pardoning. ${ }^{160}$

\section{Conclusion}

Galway jail's palimpsest of memories and representations was easily instrumentalised by Browne in his mission to build a new Catholic cathedral. Political prisoners, literary writings, even the stone and mortar of the site itself, fitted conveniently into a narrative of renewal, triumphalism, and memorialisation. No other Catholic cathedral built in twentieth-century Ireland benefitted from such a historically productive site. Yet the legacy of Maamtrasna and Joyce's execution - at those particular moments where and when it entered the site's memorialisation narrative complicated the question of the jail's future use. As Beaumont argues, contested or 'difficult' heritage can mean different things at different times, and for different people. ${ }^{161}$ In Galway these

${ }^{160}$ Colm Bairéad and Seán Ó Cuirreáin, 'Murdair Mhám Trasna' (TG4 documentary, first broadcast 4 Apr. 2018); Irish Times, 31 Mar. 2018; Irish Independent, 5 Apr. 2018.

${ }^{161}$ Beaumont, 'Contested trans-national heritage', p. 300. 
conflicting representations centred on the quick-lime grave - the burial plot - inside the former jail. Undisturbed during the demolition of the jail buildings, it remained as the tangible - and subterranean - legacy of the site's former use. It was the final resting place of both those prisoners such as Joyce who had maintained their innocence, but also other prisoners who wilfully admitted their guilt and involvement in serious violence, murder, and other crimes from the past, thus establishing the martyr-criminal dichotomy that contributed so much to the 'difficult' character of the site. The complexities of this are most apparent in Browne's twopronged approach to gaining possession of the site for as little financial outlay as possible: the contrast between the 'perfect symbol of the triumph of a people who were proscribed for being Irish' - and perhaps speaking Irish - and the perceived reluctance of middle-class Galway families to raise their children on a site where 'criminals were executed'. This uncertainty can also be seen in the initial and unsuccessful attempt to memorialise the burial plot in the cathedral's carpark, requiring later interventions and, arguably, only fully resolved in recent years. The condition of the memorial symbolised the unfinished nature of the campaign to clear Joyce's name: rebuilt within a few years of Waldron's pioneering and consciousness-raising study, and with a new plaque added in the era of Higgins' pardon.

Irish urban spaces of the twentieth century - and their representations - are relatively understudied in existing scholarship. ${ }^{162}$ Yet the cultural memory of urban spaces, processes of demolition, the politics of 'difficult' heritage and even the cultural understandings of ruins, are relatively well understood and theorised in studies from other countries and regions. The former Galway jail site offers a particularly rich and well-documented body of political and literary

\footnotetext{
162 Richard Butler and Erika Hanna, 'Irish urban history: an agenda', Urban History, xlvi, no. 1 (Feb. 2019), pp. 2-9, at pp. 5-6. For the nineteenth century, see Georgina Laragy, Olwen Purdue, and Jonathan Jeffrey Wright (eds), Urban spaces in nineteenth-century Ireland (Liverpool, 2018).
} 
representations, and a study akin to a biography of this space speaks for broader themes in midcentury Irish political and religious culture. Most of all it shows a political culture that encouraged - and reaped the benefits - of memorialisation and 'deep' memory. Joyce, O'Brien, Gregory, Pearse and others offered an arsenal of representations that could be instrumentalised in fundraising literature, speeches, and lobbying. Furthermore, the debate over the future of the site shows the specificities of Catholic urban power in mid-century Ireland, and the relative ease by which Browne dominated the ideological discourse on what would constitute an appropriate afterlife for the nineteenth-century prison. This article also highlights opposition to the bishop's agenda and occasional public criticisms that served to check what might otherwise appear as unopposed power and agency. Yet these did little to undermine the - perhaps predictably Catholic nature of the site's memorialisation, from Blunt's fervent study of his Bible to Joyce's classic representation as a martyr. Arguably, his martyrdom was only deepened by the diocese's monopolisation of the future of the site; the plans for a Catholic cathedral excluded other possibilities.

The representations of the jail site also show how ordinary people became involved in its memorialisation, from the city residents who encouraged to Browne to build on the site to the people - and journalists - who photographed themselves and their friends in front of the jail gate and walls as bulldozers and wrecking cranes bade farewell to Blunt's old 'dark gaol'. For many children in the city its passing signified an opportunity for urban exploration, memories of which must survive today though remain unrecorded. Furthermore, the public history element of the jail site's 'difficult' heritage is apparent in the broad campaign to pardon Joyce in recent years and in the wealth of new studies and adaptations for television and podcast by both academic and non-academic authors. This democratisation of the site's history adds a further layer of understanding to what can be gleamed from diocesan and state archives. Indeed, the engagement of ordinary people was as apparent in the 1960s as it is today. One local man, Eoin Smith, wrote 
a poem about his changing city in 1969 , not previously published. Identifying himself as a former inmate of the jail (perhaps during the revolutionary years), he sent his simple and straightforward poem, anonymously, to the bishop, where it survives in the diocesan archives. Smith ties together the many layers of historical meaning in the transition of the site from jail to cathedral, reaching back to the time of Maamtrasna and forwards to his own time:

Where once I pined in prison, when I was but a boy,

A shrine divine has 'risen in faith and hope and joy, ...

It was [Pearse and Fr. Michael Griffin] who stretched forth lifeless hands

To tear that prison down,

To build the shrine which proudly stands

Today in Galway Town.

Their martyred bones its corner stones,

Their blood its walls sustain,

Our country's pride, for this they died,

Nor have they died in vain. ...

Since Galway's new Cathedral stands

Where once stood Galway Jail.

...The trapdoor's crash and the hanging noose

Are gone for ever more.

And in their place this shrine of grace,

Guards dear old Galway bay,

How very odd, that I, thank God,

Should live to see the day. 
My hands are free unshackled now,

No bars, no bolts, no keys,

To thank my God I humbly bow,

Upon my bended knees.

For this gracious gift, from His sacred hands,

That nothing can assail,

Since Galway's new Cathedral stands

Where once stood Galway Jail. ${ }^{163}$

163 Anon. [Eoin Smith], 'Galway's new cathedral' (poem), 10 May 1969 (G.D.A., B/6/113, B/6/120). Fr. Michael Griffin (1892-1920), a Galway priest murdered by British forces on 14 Nov. 1920 during the War of Independence. 